4

11 Joshua D. Valentino ${ }^{1}$,Department of Geosciences, 4044 Derring Hall, Virginia Tech, Blacksburg,

12 VA 24061, USA joshua1 @ vt.edu

13

14

16

17

28

\section{ROCK UPLIFT AT THE TRANSITION FROM FLAT-SLAB TO NORMAL SUBDUCTION: THE KENAI MOUNTAINS, SOUTHEAST ALASKA}

\author{
Submitted to Tectonophysics, 14 August 2015
}

Revised for Tectonophysics, 8 January 2016

\section{James A. Spotila, Department of Geosciences, 4044 Derring Hall, Virginia Tech, Blacksburg,} VA 24061, USA spotila@vt.edu

16

Lewis A. Owen, Department of Geology, University of Cincinnati, Cincinnati, OH 45221, USA owenls@ucmail.uc.edu

Jamie T. Buscher, Andean Geothermal Center of Excellence (CEGA) and Department of Geology, Facultad de Ciencias Físicas y Matemáticas, Universidad de Chile, Plaza Ercilla 803, Santiago, Chile. jbuscher@vt.edu

\footnotetext{
${ }^{1}$ Corresponding Author
} 


\section{Abstract}

The process of flat-slab subduction results in complex deformation of overlying forearcs,

31 yet how this deformation decays with distance away from the zone of underthrusting is not well

32 understood. In south central Alaska, flat-slab subduction of the Yakutat microplate drives

33 shortening and rock uplift in a broad coastal orogenic belt. Defined limits of the zone of

34 underthrusting allow testing how orogenesis responds to the transition from flat-slab to normal

35 subduction. To better understand forearc deformation across this transition, apatite (U-Th)/He

36 low temperature thermochronometry is used to quantify the exhumation history of the Kenai

37 Mountains that are within this transition zone. Measured ages in the northern Kenai Mountains vary from 10-20 Ma and merge with the exhumation pattern in the Chugach Mountains to the

39 northeast, where high exhumation occurs due to flat-slab-related deformation. In the southern

40 Kenai Mountains, however, ages increase to 30-50 Ma across a transition near Seward, Alaska,

41 above the zone from flat-slab to normal subduction. These ages are relatively old in comparison

42 to ages determined in other studies in southern Alaska and suggest minimal exhumation.

43 Furthermore, transitions in topographic expression of the coastal orogen also occur at the margin

44 of Yakutat underthrusting. These observations suggest that either deformation associated with

45 flat-slab subduction requires tens of kilometers to decay with distance away from the zone of

46 underthrusting, or that orogenesis in the Kenai Mountains is driven by a distinct tectonic cause.

47 A potential driver of deformation is underplating of thick sediments, specifically the Surveyor

48 Submarine Fan, along the Aleutian Megathrust, analogous to the tectonic mechanism responsible

49 for the emergence of the Kodiak Island forearc. If correct, this may represent a recent tectonic

50 transition in the region, given the minimal exhumation of the rugged Kenai Mountains despite

51 the presence of an erosion-conducive glacial climate. 
52 Key Words: Flat slab subduction, Kenai Peninsula, Low-Temperature thermochronometry,

53 Exhumation, Topography

54

55 1. Introduction

Deformation in the upper plate of subduction zones relates to the orientation and

57 morphology of the down-going plate (Fisher et al., 1998; Brandon et al., 1998; Dominguez et al.,

58 2000). Lateral transitions in slab dip and morphology along a trench can lead to complex

59 patterns of forearc development and uplift. For example, a change in subduction angle from steep

60 to flat-slab may cause a gradual increase in upper plate shortening and rock uplift (Gutscher et

61 al., 2000). Instances of flat-slab subduction in Central America and the Andes show that

62 widespread deformation and uplift above the flat section decreases in intensity with gradual

63 increase in subduction angle (Gutscher et al., 2000; Ramos et al., 2002). How upper plates

64 respond along sharp transitions in slab subduction and geometry is less well known.

The Kenai Peninsula is part of a $\sim 2000 \mathrm{~km}$ long exhumed accretionary prism and forearc

66 along the southern margin of Alaska (Figure 1) (Plafker et al., 1989). The region undergoes

67 active rock uplift related to flat slab subduction, oblique collision, and accretion of the Yakutat

68 microplate (Plafker \& Berg, 1994; Haeussler et al., 2000). Intense deformation and exhumation

69 occurs in the Wrangellia-St. Elias and Chugach Mountains, which are undergoing accretion

70 directly related to Yakutat collision (Spotila \& Berger, 2010; Arkle et al., 2013; Enkelmann et

71 al., 2015). The mountainous forearc continues beyond the Yakutat microplate to where normal

72 subduction of the Pacific plate occurs along the Aleutian Megathrust. The coastal mountains are

73 rugged, have high topography (mean elevation $1000 \mathrm{~m}$ above sea level [asl]), and are deeply

74 incised by glaciers (Buscher et al., 2008). The Kenai Mountains span both the western limit of 
75 the Yakutat plate and normal Pacific plate subduction, providing a unique opportunity to study

76 deformation across a sharp transition in down going slab geometry and morphology.

77 The approach of this study is to provide a first order constraint on the timing and

78 magnitude of exhumation across the Kenai Mountains from which no previous

79 thermochronometry has been documented. We measured apatite (U-Th)/He ages (AHe) across

80 the Kenai Peninsula to test the effect of the slab transition on deformation of the forearc.

81 Specifically, we sought to test whether a localized zone of rapid rock uplift occurred outside of

82 the lateral transition zone away from the Yakutat plate, as suggested by the distribution of rugged

83 topography. Our results using difficult lithologies provide the first quantitative values for

84 exhumation associated with the unique tectonic transition.

\section{Background}

\section{2.1. Flat Slab Subduction in Southern Alaska}

Flat slab subduction drives upper plate deformation and orogenesis that can penetrate

89 hundreds of kilometers into overriding continental lithosphere (English et al., 2003; Li \& Li,

90 2007; Ramos et al., 2002). The common view is that flat slab subduction is linked to buoyant

91 oceanic crust associated with thickened oceanic plateaus, hot-spot trails, or rapidly subducting,

92 young slabs. After onset of flat slab subduction, upper plate shortening propagates landward and

93 drives exhumation and broad surface uplift of the forearc, magmatic arc, and back arc basin,

94 development of fold-thrust belts with widespread fault reactivation, and migration of arc

95 volcanism (Little \& Naeser, 1989; Berger et al., 2008; Gutscher et al., 2000; Ramos et al., 2002;

96 Finzel et al., 2011;Gardner et al., 2013). Tectonic underplating of the slab and overlying off- 
97 scraped sediments may also contribute to uplift and exhumation (Fuis et al., 2008; Ducea et al., 98 2009).

Flat slab subduction is hypothesized to be the primary cause of modern orogenesis in 100 southern Alaska (Plafker, 1987; Bruhn et al., 2004; Abers, 2008; Haeussler et al., 2008; Riccio et 101 al., 2014). The driver for flat slab subduction is considered to be the Yakutat microplate, an 102 exotic terrain consisting of an over-thickened $(11-22 \mathrm{~km})$ oceanic plateau that collides at $10350 \mathrm{~mm} / \mathrm{yr}$ into and subducts at a low angle beneath the North American plate (Figure 1,3; Plafker 104 et al., 1994; Fletcher \& Freymueller, 1999; Haeussler et al., 2003; Freymueller et al., 2008; 105 Christeson et al., 2010; Elliott et al., 2010; Worthington et al., 2012). Flat slab subduction and 106 associated collision in the St. Elias orogen initiated in the Middle Miocene (Plafker et al., 1994;

107 Perry et al., 2009; Enkelmann et al., 2010). The leading edge of the Yakutat plate is now located $108 \sim 250 \mathrm{~km}$ northwest of the subduction zone at $150 \mathrm{~km}$ depth under central Alaska (Ferris et al., 109 2003). The western trailing edge of the Yakutat plate is situated underneath northern Kenai 110 Peninsula today and bends alongside the down going Pacific plate (Figure 1,3; Eberhart-Phillips 111 et al., 2006; Fuis et al., 2008). Flat subduction of the Yakutat plate drives convergent 112 deformation and orogenesis for hundreds of kilometers throughout the overriding plate 113 (Mazzotti\& Hyndman, 2002; Bruhn et al., 2004). The effect of this deformation includes 114 widespread acceleration of exhumation (Enkelmann et al., 2010; Spotila \& Berger, 2010), basin 115 inversion (Finzel et al., 2011; Ridgway et al., 2011), and cessation of subduction related 116 volcanism since the Eocene (Pavlis \& Roeske, 2007). Although the effects of Yakutat subduction are clearly expressed in the central and southern Alaska mountain ranges that lie directly above it, including the St. Elias, Chugach, 119 Tordrillo, Talkeetna, and Alaska Ranges (Spotila \& Berger, 2010; Arkle et al., 2013; Hauessleret 
120 al., 2008), the spatial and temporal characteristics of the transition to areas beyond the leading

121 edge of the subducting microplate are not clear. Deformation related to the Yakutat plate has

122 been suggested to penetrate $600-800 \mathrm{~km}$ northeast and $150-200 \mathrm{~km}$ northwest of the collision

123 zone (Figure 1; Mazzotti\& Hyndman, 2002; Finzel et al., 2011). Evidence for this deformation

124 is seen in basin inversion and faulting away from the immediate zone of Yakutat subduction

125 (Pavlis \& Roeske, 2007; Ridgway et al., 2007; Finzel et al., 2011; Haeussler and Saltus, 2011),

126 but it is not fully understood how upper plate deformation decreaseswith distance from the

127 subducting slab or what transitions occur at the margin of the slab. The Kenai Peninsula is an

128 example of such a location that lies at the transitional zone just outside of Yakutat flat slab

129 subduction.

130

$131 \quad$ 2.2. The Kenai Peninsula

132 The Kenai Peninsula is a northeast trending forearc high situated along the transition 133 from flat slab subduction of the Yakutat plate to normal subduction of the Pacific plate beneath

134 southern Alaska (Figure 1). The peninsula forms the westernmost component of a continuous arc

135 of mountainous topography that extends as far east as the Fairweather Range (Buscher et al.,

136 2008). The rugged Kenai Mountains are located along the peninsula south of the Turnagain Arm,

137 and is the southwestern continuation of the Chugach Mountains to the northeast. Although the

138 Kenai Mountains are situated to record the changes in deformation and rock uplift that occur at

139 the edge of flat subduction, little is known about its recent deformational and denudational

140 history.

The Kenai Peninsula is composed of the Cretaceous and early Tertiary Chugach and

142 Prince William terranes and associated Tertiary-Neogene cover over the Jurassic terrane 
143 underlying the Kenai lowlands (Figure 2). These terranes were accreted to the forearc in the Late 144 Cretaceous to early Tertiary via motion on the Border Ranges and Contact faults (Freeland \& 145 Dietz, 1973; Plafker et al., 1989; Plafker \& Berg, 1994; Haeussler et al., 2003; Fuis et al., 2008). 146 The terranes were metamorphosed and intruded due to subduction of the Kula-Resurrection ridge 147 from 57-52 Ma (Haeussler et al., 2003; Bradley et al., 2000). The Yakutat plate began subducting 148 beneath the southern margin of Alaska by 32-23 Ma, and reached the forearc by Late Oligocene 149 and Early Miocene (Plafker et al., 1994; Haeussler et al., 2003; Finzel et al., 2011). The uplift of 150 the Kenai Peninsula may have been related to passage of the Yakutat plate beneath it.

151 Sedimentary and stratigraphic relationships in Cook Inlet suggest that emergence and erosion of 152 the Kenai Mountains began during the Miocene and became the predominant source of sediment 153 by the Late Miocene (Kirschner and Lyon, 1973). The Beluga formation records the onset of 154 widespread deposition from the Kenai Mountains and is characterized by conglomeratic 155 sandstones and the presence of epidote which is uniquely characteristic of the Chugach terrane 156 (Kirschner and Lyon, 1973). This timing roughly matches when the Yakutat microplate passed 157 underneath the peninsula. The EDGE seismic transect between the Kenai Peninsula and Kodiak 158 Island revealed an erosional backstop, where the accretionary prism is absent and older Eocene 159 strata occur (Ye et al., 1997; von Huene et al., 1998; von Huene and Klaeschen, 1999). This 160 unconformity is interpreted to be related to the passage of the trailing edge or southwest margin 161 of the Yakutat plate beneath the region, and stratigraphic relationships place the timing of this 162 event at 3.5 Ma (von Huene et al., 1998). The orientations and movements of the Yakutat and 163 Pacific plates since 3.5 Ma have caused the trailing edge to migrate to the northeast underneath 164 the Kenai Peninsula until it reached the present position under northernmost Kenai Peninsula and 165 Sargent Ice field (von Huene et al., 1998; Pavlis et al., 2004; Eberhart-Phillips et al., 2006). 
Pacific Plate subduction (Haeussler et al., 2003). The axis of the peninsula lies $\sim 250 \mathrm{~km}$ from the modern trench (Figure 1). Farther north in the Chugach Mountains, which lie directly above the subducting Yakutat microplate, convergence is thought to have been primarily accommodated via thrusting and rock uplift on the Contact fault since the Mid-Miocene (Arkle et al., 2013). The role of the Contact fault in deformation along the Kenai Peninsula has not yet been defined. The Border Ranges fault is the other major fault in the region and is thought to act as the modern backstop to forearc deformation in the Chugach and Kenai Mountains (Plafker et al., 1989; Plafker \& Berg, 1994; Arkle et al., 2013). The Border Ranges fault experienced dextral and contractional reactivation in the Neogene, but is buried by undeformed late Tertiary glacial deposits along the Kenai Mountains (Pavlis\& Bruhn, 1983; Little \& Naeser, 1989; Plafker et al., 1989; Plafker \& Berg, 1994). Contractional deformation also occurs west of the Kenai Peninsula in the Cook Inlet. This forearc basin consists of a succession of Mesozoic and Cenozoic sediment, sourced from the surrounding mountains, that are $12 \mathrm{~km}$ - and $7 \mathrm{~km}$-thick, respectively (Fisher \& Magoon, 1978; Bruhn \& Haeussler, 2006). Active shortening in the basin due to coupling along the megathrust ranges from 0.3 to $2.7 \mathrm{~mm} / \mathrm{yr}$ and is manifest as a series of Pliocene to Quaternary anticlines and several $\mathrm{mm} / \mathrm{yr}$ dextral and reverse slip along the Castle Mountain and Bruin Bay faults (Hartman et al., 1974; Cohen \& Freymueller, 1997; Haeussler et al., 2000; Parry et al., 2001; Bruhn \& Haeussler, 2006; Willis et al., 2007) (Figure 3). This recent deformation has been attributed to a combination of the Yakutat collision to the east and subduction of the Pacific plate below the region (Haeussler et al., 2000).

Although sedimentary records in Cook Inlet suggest that the Kenai Mountains began eroding during the Late Miocene, the spatial pattern, magnitude, and rate of uplift and erosion 
are not constrained. The Kenai Mountains consists of a 150-km-long elliptical mountainous region that is the southern continuation of the coastal orogen (Figure 3). The Kenai Mountains have an average height of $\sim 2000 \mathrm{~m}$ asl and tapers gradually to the west, where it is juxtaposed by the Border Ranges fault, causing an abrupt linear trend against the Cenozoic fill of Cook Inlet. On the east the range is dissected by glacial fjords, where cirques are submerged below sea level.

The apparent subsidence on the east flank of the mountains is estimated to be $\sim 100-300$ meters (Plafker, 1969) which may have been caused by a combination of rising sea level, climate changes during the LGM, and dynamic subsidence. The summits of the Kenai Mountains are heavily glaciated, capped by the Sargent and Harding icefields. These icefields give the range a welt-like appearance, as an elliptical concentration of high elevation that tapers off radially before merging with the Chugach Mountains (Figure 4). Because of the presence of glaciers, mean slopes for Alaska mountain ranges are lower than expected based on the steepness of bare bedrock surfaces (Buscher et al., 2008). In the Kenai Mountains, for example, unglaciated surfaces above modern glacial trimline tend to be at or beyond the angle of repose. Nonetheless, the average slope in the Kenai Mountains $\left(17^{\circ}\right)$ is comparable to that observed in both the Chugach $\left(19^{\circ}\right)$ and St. Elias $\left(16^{\circ}\right)$ ranges, both of which lie directly over the Yakutat slab (Buscher et al., 2008; Arkle et al., 2013). The welt-like nature of the Kenai Mountains is also apparent in the geometry of drainage basins (Figure 5). North of the Kenai Mountains, the main divide occurs near the eastern edge of the peninsula, whereas in the Kenai Mountains the divide steps west to the central axis of the peninsula and separates much smaller basins. The concentration of high elevation, relief, and glacial coverage into a welt in the Kenai Mountains suggests it may be a locus of rock uplift, similar to the bull's eye of rock uplift in the comparably 
211 rugged western syntaxis of the Chugach Mountains at the north end of Prince William Sound 212 (Arkle et al., 2013).

Glacial climate and associated glacial and periglacial processes are probably a

214 contributing factor to the ruggedness of the Kenai Mountains. The eastern side of the Kenai

215 Peninsula experiences a wet maritime climate with $\sim 180 \mathrm{~cm} / \mathrm{yr}$ precipitation, whereas the

216 western side experiences a colder continental interior climate with only $\sim 50 \mathrm{~cm} / \mathrm{yr}$ precipitation

217 (National Oceanic and Atmospheric Administration, 2004, 2007). A result of this orographic

218 gradient is heavier glaciation of the eastern flank, where glacial equilibrium line altitude (ELA)

219 drops to $\sim 800 \mathrm{~m}$ asl, whereas on the western flank ELA is above 1,200 $\mathrm{m}$ asl (Péwé, 1975; Mann

220 \& Peteet, 1994; Wiles et al., 1995). During the local last glacial maximum, estimated to have

221 been $~ 23 \mathrm{ka}$ for this region (Karlstrom, 1961), the ELA was 300-500 m lower and glaciers

222 covered the majority of the peninsula (Wiles et al., 1995). Based on the warm maritime setting,

223 glaciers throughout the Quaternary on the Kenai Peninsula are likely to have been wet-based and 224 therefore highly erosive (Péwé, 1975).

225 The exhumation history of the Kenai Mountains has not yet been documented because of 226 a lack of previous low temperature thermochronometry in the coastal orogen (Figure 1).

227 However, previous work has defined the exhumation pattern of neighboring ranges. Apatite 228 fission-track and (U-Th)/He ages from the Chugach and St. Elias ranges reveal rapid exhumation 229 of $>1 \mathrm{~mm} / \mathrm{yr}$ and up to $5 \mathrm{~mm} / \mathrm{yr}$ in the core of the Yakutat collision zone, tapering away to $<0.1$ $230 \mathrm{~mm} / \mathrm{yr}$ to the north and west (Spotila et al., 2004; Enkelmann et al., 2010; Spotila \& Berger, 231 2010). Local concentrations of late Cenozoic exhumation of 0.4-0.5 mm/yr occur in a bull's eye 232 of the western Chugach syntaxis at Mount Marcus Baker and along splay faults in Prince 233 William Sound, including on the Patton Bay fault on Montague Island (Arkle et al., 2013; 
234 Ferguson et al., 2015; Haeussler et al., 2015). These exhumation hotspots decay to average rates

235 of $<0.05 \mathrm{~mm} / \mathrm{yr}$ in the Chugach Mountains and northern portion of the Kenai Peninsula (Buscher

236 et al., 2008). Testing whether a hotspot of exhumation occurs in the Kenai Mountains and

237 relating this exhumation to regional tectonics are the main goals of this study.

238

239

\section{Methods}

Low temperature thermochronometry was used to constrain the exhumation history of the

241 Kenai Mountains. We obtained seventeen new apatite AHe ages across the region, where no

242 previous low temperature thermochronometry had been completed. Sample locations were

243 broadly distributed to provide regional spatial coverage, although locally samples were clustered

244 to provide a range of elevation. However, rugged terrain prevented the collection of good vertical

245 sample profiles. Samples were collected via helicopter and where trail access was possible. AHe

246 ages are based on the radiogenic production and thermal diffusion of ${ }^{4} \mathrm{He}$ and recordcooling from

247 closure temperatures of $\sim 50-70{ }^{\circ} \mathrm{C}$, or exhumation from $\sim 2-3 \mathrm{~km}$ depth for typical geothermal

248 gradient (i.e. $25^{\circ} \mathrm{C}$ ) (Farley, 2000; Ehlers \& Farley, 2003). Closure temperatures for AHe are

249 dependent on multiple factors, however, including cooling history, crystal grain size, and

250 radiation damage (Farley, 2000; Ehlers \& Farley, 2003; Flowers et al., 2009; Brown et al., 2013).

251 AHe ages were measured at Virginia Tech on both single and multigrain aliquots. Dated

252 apatite grains were generally $>70 \mu \mathrm{m}$ in diameter and were selected under 100x magnification

253 based on distinct crystal habit, birefringence, relief, and lack of obvious microinclusions or

254 fractures. Aliquots were outgassed in Pt tubes in a resistance furnace at $950{ }^{\circ} \mathrm{C}$ for 20 min and

255 analyzed for ${ }^{4} \mathrm{He}$ by ${ }^{3} \mathrm{He}$ spike and quadrupole mass spectrometry. Radiogenic parent isotopes

256 were measured at the University of Arizona using isotope dilution and ICP mass spectrometry. 
257 Predicted age uncertainty is $\sim 5 \%(1 \sigma)$, based on instrument precision and $F_{T}$ calculations (Farley,

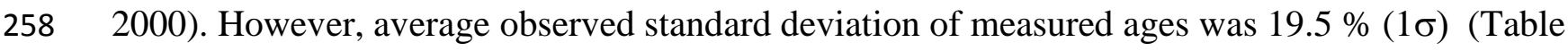
259 1). In addition, 19 outlier age determinations (17\% of total) were culled from the data set prior to 260 the calculation of mean ages, on the basis that they were more than double the mean age and thus 261 likely anomalous (Table 1). Comparably large uncertainties have been observed in other nearby 262 studies (11-17\%, 1б) (Buscher et al., 2008; Arkle et al., 2013; Ferguson et al., 2015), suggesting 263 that local lithologies (graywacke, metaflysch) are problematic for AHe dating. For this reason, 264 we took the approach of Berger et al. (2008) and measured a high number of replicate analyses 265 per sample ( $\sim 6$, but as high as $n=13)$ to improve reproducibility. Several samples $(12 \mathrm{Kn} 7,12 \mathrm{Kn} 8,12 \mathrm{Kn} 12)$ had particularly poor reproducibility that 267 seems to relate to poor apatite quality, crystal grain size, and abundance. Figure 6 shows 268 example apatite grains and lithologies that are representative of these samples. Reasonable 269 quality apatite occurred in some samples that are typical of other studies (A and B in Figure 6). 270 In contrast, many of the apatites were opaque, broken along their basal cleavage, i.e., parallel to 271001 plane, or fractured (C-G in Figure 6). The surfaces of many grains were also frosted, etched, 272 or rounded, possibly associated with sedimentary transport and post-burial alteration.

273 Anomalously old ages may result from the presence of radiogenic microinclusions that went 274 undetected in these visually imperfect grains. Observed age dispersion may also result from the 275 occurrence of fractures or other crystal imperfections, which introduce the possibility for loss of $276{ }^{4} \mathrm{He}$, loss of parent radiogenic material, and complications in correctly measuring $F_{T}$ values

277 (Brown et al., 2013). Differences in chemistry, parent atom zonation, and radiation damage are 278 other potential causes of age dispersion (Flowers et al., 2009), particularly given that our samples 279 are sedimentary or metasedimentary in origin and thus consist of multi-sourced detrital apatite. 
280 Rough positive correlations between $\mathrm{eU}$ and $\mathrm{AHe}$ age for several samples suggest that radiation

281 damage could be a contributing factor to the observed age dispersion. However, a surprising

282 result of this study is that measured ages on large, fractured, opaque single grain with

283 microinclusions, which traditionally would have been avoided, reproduced reasonably well $(\mathrm{H}$

284 and I in Figure 6).

285

286 4. Results

287

288

ages are relatively old in comparison to other studies in southern Alaska (e.g. Spotila \& Berger,

2010; Arkle et al., 2013; Ferguson et al., 2015) and are not indicative of recent, rapid

290 exhumation. The "bull's eye" of young ( $<5 \mathrm{Ma})$ AHe ages identified north of Prince William

291 Sound (Arkle et al., 2013), for example, does not extend southwards into the Kenai Mountains,

292 despite the rugged topography of the range that would suggest recent uplift and erosion.

293

Ages in the north, closest to the Chugach Mountains, are the youngest measured (10-20

294 Ma). These ages overlap with those determined by Buscher et al. (2008) and Arkle et al. (2013)

295 and are relatively consistent across the entire Chugach Mountains from the Cook Inlet to Prince

296 William Sound. Ages increase to 30-50 Ma in the central and southern Kenai Mountains. The

297 ages are generally 40-50 Ma on the west and $25 \mathrm{Ma}$ on the Pacific coast (Figure 7a). This trend

298 is consistent with observations by Buscher et al. (2008) farther north in the Chugach Mountains,

299 which are interpreted to represent an AHe partial retention zone that was tilted up on the east via

300 greater exhumation along the Pacific coast. However, existing sample coverage does not permit

301 a unique characterization of AHe isochron geometry. Likewise, sample coverage does not permit 
302 determination of age-elevation relationships. The few samples that do span a range of relief in

303 close proximity to each other do not indicate an obvious age-elevation trend.

Although measured ages become younger to the southeast towards the Contact fault, they

305 do not bear any other obvious relationship to mapped faults. However, one measured age may

306 require a local tectonic explanation. Sample $12 \mathrm{Kn} 13$ from the southern part of the peninsula

307 produced a younger age $(9.5 \mathrm{Ma})$ that does not fit with the regional pattern (Figure 2). Given that

308 only one sample in the region shows this young age, however, we consider it to be an

309 unexplained local phenomenon and additional data would be required to understand its

310 significance.

311 The old AHe ages measured in this study are older than any ages previously measured in

312 southern Alaska. The older ages measured in this study roughly correlate with the early Cenozoic

313 ages measured previously in the Tordrillo Mountains (Haeussler et al., 2008). The three oldest

314 ages in the Tordrillo Mountains $(39,48$, and $74 \mathrm{Ma}$ ) were shown to be affected by apatite

315 zonation, but these ages may also represent a slow background exhumation rate, similar to the

316 older ages in the Kenai Mountains. The older AHe ages from the Kenai Mountains overlap with

317 higher temperature cooling ages that suggest widespread rapid cooling post $~ 52 \mathrm{Ma}$ (Helwig \&

318 Emmet, 1981; Bradley et al., 2000). This cooling event corresponds to a subduction of a slab

319 window around $\sim 55 \mathrm{Ma}$ (Bradley et al., 2000). Our ages suggest that cooling to apatite closure

320 temperatures must have been very rapid following this event. Since this cooling event, the upper

321 crust must have been relatively stable and only slowly exhumed, allowing formation of a partial

322 retention zone (PRZ).

\section{5. Discussion}


Despite its rugged topography, the Kenai Mountains do not appear to contain a locus of

326

327

328

329

330

331

332

333

334

335

336

337

338

recent, rapid exhumation. Measured AHe cooling ages of 40-55 Ma are the oldest that have been measured along the coastal orogen of south-central Alaska. These ages imply that rocks of the Kenai Peninsula must have cooled quickly after passage of a slab window in early Cenozoic (Bradley et al., 2000), but subsequently experienced minimal exhumation and prolonged crustal stasis. Based on the oldest cooling age, a calculated closure temperature of $\sim 58{ }^{\circ} \mathrm{C}$, and an assumed geothermal gradient of $\sim 22^{\circ} \mathrm{C} / \mathrm{km}$ calculated from the temperature logs of COST No. 1 well in Cook Inlet (Magoon, 1986), the average exhumation rate since 50 Ma has only been $\sim 0.05 \mathrm{~mm} / \mathrm{yr}$, although we do not expect that exhumation would have been constant throughout the Cenozoic. An alternative explanation for the observed AHe ages is that the geothermal gradient in the forearc is lower than implied by Magoon (1986). Subduction refrigeration can accompany flat slab subduction, in which the cold down-going slab cools the overlying mantle wedge and decreases geothermal gradient by as much as $10-15^{\circ} \mathrm{C} / \mathrm{km}$ (Dumitru et al., 1991; Peacock, 1996; Westaway, 2006). If the geothermal gradient was much reduced following passage of a slab window beneath the Kenai Mountains, this could have rendered the $\mathrm{AHe}$ system insensitive to subsequent exhumation of even several kilometers. Without independent constraints on the mid to late Cenozoic geothermal gradient, however, this possibility is difficult to assess. We therefore elect to interpret our data using the best known estimate of current geothermal gradient (Magoon, 1986), while acknowledging the caveat that a lower than expected geothermal gradient could account for some of the spatial variation and great antiquity of the observed ages.

Although future work will be required to better determine age-elevation relationships in the area, the high variation in old AHe ages across minimal elevation range implies the 
occurrence of an AHe PRZ in the Kenai Mountains. The spatial variation in ages can be loosely fit by closely stacked isochrons of a PRZ that is tilted gently down to the west away from the windward side of the range (Figure 7b). The orientation and location of the isochrons are

351 difficult to define and non-unique, due to differences in sample elevation and scatter in the AHe 352 ages. The crustal section containing this potential PRZ is less deeply eroded than the PRZ in the 353 Chugach Mountains in the vicinity of Turnagain Arm, where ages are slightly younger (10-20 354 Ma) (Buscher et al., 2008). In regional context, it therefore appears that the locus of rapid 355 exhumation in the Chugach Mountains north of Prince William Sound identified by Arkle et al. 356 (2013) transitions gradually to a zone of moderate exhumation in the westernmost Chugach 357 Mountains and to a zone of minimal exhumation farther southwest into the Kenai Mountains 358 (Figure 8). The transition from moderate to minimal exhumation near Seward is sharp and may 359 represent the progressive change from the trailing edge of the Yakutat plate to the Pacific plate. If the crest of the Kenai Mountains has experienced minimal erosion, the shape of the 361 topography itself should represent the geometry of surface uplift responsible for creating the 362 range. Topographic profiles show that the Kenai Mountains are a broad dome (Figure 4). The 363 dome has a sharp, fault-bounded western margin. Total recent exhumation into this dome has 364 been limited to valley incision, without lowering of upper ridge surfaces. In the northern Kenai 365 Mountains the dome is deeply incised, whereas in the south the dome is capped by the Harding 366 Icefield. Across the dome the elevation of peaks and ridges are somewhat concordant and can be 367 used to define an imaginary surface that represents the limit of recent rock uplift (Figure 4) 368 (Buscher et al., 2008). This dome could be produced as doubly-plunging antiformal arc of rock uplift. If correct, this interpretation suggests that the Kenai Mountains are a transient landform 370 with erosion that lags behind surface uplift and creation of topographic potential energy (e.g. 
371 Ouimet et. al., 2009; Oskin and Burbank, 2005). The Kenai Mountains may thus provide an

372 example of a range in the early stage of orogenesis that is in a state of disequilibrium with the

373 local erosional setting. A minor influence of climate on exhumation pattern may be apparent in

374 the Kenai Mountains, however. The decrease in AHe age to the southeast and implied greater

375 depth of erosion into the PRZ of $\sim 0.5-1.0 \mathrm{~km}$ may be due to heavier precipitation and lower

376 glacial ELA on the Pacific Coast (Figure 7b).

377 Several lines of evidence combine with the relatively old AHe ages of the Kenai

378 Mountains to suggest that they are kinematically distinct from the Chugach Mountains to the

379 north. The gross topography of the Kenai Mountains appears disconnected and offset from the

380 core of the Chugach Mountains at the southern margin of the underthrusting Yakutat microplate.

381 The main drainage divide and axis of highest topography in the Kenai Mountains are situated in

382 the center of the peninsula, whereas north of Seward in the Chugach Mountains the divide and

383 topographic axis are located near the eastern margin of the mountains close to Prince William

384 Sound, corresponding to much larger western catchments and glacial valleys (Figures 3 and 5).

385 The topographic crest jumps approximately $30 \mathrm{~km}$ to the west south of Seward and also changes

386 orientation from north-south in the Chugach Mountains to NE-SW in the Kenai Mountains

387 (Figure 3). Greater erosion in the Chugach Mountains may have pushed the regional drainage

388 divide to an axis of uplift in Prince William Sound near active faults like the Contact fault (Arkle

389 et al., 2013). The locus of rock uplift in the Kenai Mountains may instead be focused in the

390 middle of the peninsula, or a lower degree of erosion may have so far left the master divide in the

391 Kenai Mountains immune to lateral shifts related to faulting, precipitation gradient, or glacier

392 headward retreat. These transitions correspond to physical trends in the neighboring Cook Inlet.

393 A shallowing of basin thickness to the south and increase in gravity anomalies roughly coincides 
with where AHe ages increase to the southwest of Seward (Mankhemthong et al., 2013).This

395 suggests the tectonic rock uplift of the Kenai Mountains and deformation and subsidence in

396 Cook Inlet may be related to each other, yet distinct from the deformation and uplift of the

397 Chugach Mountains to the north.

Although it is possible that the deformation associated with flat slab subduction that is

399 observed in the Chugach Mountains (Arkle et al., 2013) gradually tapers off with distance from

400 the underthrusting plate, the transitions in exhumation and topography around Seward (Figure 3),

401 within the transition zone of slab dip from flat to normal subduction, suggest a fundamental

402 change in tectonic origin of forearc deformation. An alternative explanation for uplift of the

403 Kenai Mountains other than from the underthrusting Yakutat microplate is underplating along

404 the Aleutian megathrust. Underplating along a subduction zone occurs when subducting

405 sediment and oceanic crust adhere to the upper plate, because of down going plate roughness,

406 over-thickened sedimentary cover, or mantle wedge melting (Zhou and Li, 2000;Ducea et al.,

407 2009).The subducting Pacific plate is covered by thick deposits derived from the surrounding

408 orogens, which could inhibit subduction and lead to underplating (Pavlis and Bruhn, 1983).

409 Surveyor submarine fan deposits are up to $4 \mathrm{~km}$ thick offshore the Kenai Peninsula and stretch

410 from the St. Elias orogen to the southern edge of Kodiak Island (Reece et al., 2011; Figure 1).

411 The associated accretionary prism offshore of the Kenai Peninsula has a broad mid-slope terrace

412 unlike the surrounding region along the Aleutian trench, which is indicative of being influenced

413 by a region of a rough down-going plate (Fruehn et al., 1999; von Huene and Klaeschen, 1999).

414 Ye et al. (1997) identified a low velocity zone along the seismic EDGE transect which was

415 interpreted as underplated sediments. In addition, a mid to upper plate discontinuity dipping $\sim 20^{\circ}$

416 to the northwest underneath the Kenai Peninsula was previously discovered by Stephens et al. 
417 (1990).Underplating on Kodiak Island is thought to occur near the brittle-ductile transition $(\sim 10$

$418 \mathrm{~km}$ depth) and result in widespread penetrative shortening and exhumation(Clendenen et al.,

419 2003; Carver and Plafker, 2008). Our results imply that the Kenai Mountains are experiencing

420 rock uplift due to forearc growth associated with underplating processes that are comparable to

421 those inferred for the longer history of deformation on Kodiak Island (Pavlis \& Bruhn, 1983).

422 If underplating has been responsible in part for rock uplift of the Kenai Mountains, it is

423 unclear when this process began and what fraction of uplift it is responsible for. Stratigraphic and

424 provenance relationships in Cook Inlet imply that the Kenai Peninsula became emergent in the

425 Late Miocene (Kirschner and Lyon, 1973; Finzel et al., 2011), although it is not clear how high

426 or widespread the mountainous topography was at this time. In contrast, the low exhumation

427 implied by our data suggests that surface uplift has outpaced rock uplift, which we expect should

428 require a recent pulse of surface uplift given the highly erosive nature of the temperate maritime

429 glacial setting. Erosion rates in this setting could easily be $>1 \mathrm{~km} / \mathrm{Ma}$ (Riihimaki et al., 2005;

430 Koppes \& Hallet, 2006; Headley et al., 2013), which would have resulted in reset AHe cooling

431 ages and removal of the PRZ in only a few million years. It is thus possible that the Late

432 Miocene emergence of the peninsula involved minimal topographic growth, and that the majority

433 of the Kenai Mountain relief has been produced only in the last few million years. One possible

434 explanation is that the Late Miocene uplift of the Kenai Peninsula resulted from passage of the

435 Yakutat microplate below it. Based on tectonic models, the trailing edge of the microplate should

436 have passed between Kodiak Island and the tip of the Kenai Peninsula at about 3.5 Ma, and

437 subsequently would have tracked north under the Kenai Mountains to its present position (Figure

438 1) (DeMets et al., 1990; von Huene et al., 1998; von Huene and Klaeschen, 1999; Fruehn and

439 von Huene, 1999; Pavlis et al., 2004). Significant underplating may have then begun in the 
440 absence of the microplate and arrival of the thickly blanketed subducting slab, resulting in a 441 renewed phase of rock uplift for the Kenai Mountains. If underplating is indeed active beneath

442 the Kenai Mountains, it is possible that continued rock uplift will eventually grow the Kenai

443 Peninsula southwards to eventually connect with Kodiak Island.

444

445 6. Conclusions

Although the topography of the Kenai Mountains is rugged, suggesting rapid

447 exhumation, measured AHe ages are older here than in other southern Alaska mountain ranges.

448 These results were only obtainable via extensive replicate dating of sub-optimal apatite grains, 449 given the challenging nature of the local bedrock. The old AHe ages indicate that the Kenai 450 Mountains have not experienced recent, rapid exhumation of sufficient magnitude to reset the 451 AHe thermochronometer $(\sim 1-2 \mathrm{~km})$. The Kenai Mountains are therefore distinct from the locus 452 of sustained concentrated rock uplift that has been identified in the Chugach Mountains north of 453 Prince William Sound (Arkle et al., 2013). The minimal exhumation and topographic character 454 suggest that the Kenai Mountains have distinct uplift kinematics from the rest of the coastal 455 orogenic belt to the north and east. We hypothesize that early emergence of the Kenai Peninsula 456 was driven by flat slab subduction, as the trailing edge of the subducting Yakutat plate passed 457 northeastwards below it between the Late Miocene and Pliocene. We further hypothesize that a 458 subsequent, localized pulse of rock uplift has occurred recently in the area of the Kenai 459 Mountains due to underplating associated with thick sediments that sit atop the subducting 460 Pacific Plate. This would make the modern Kenai Mountains analogous to the forearc 461 deformation that has produced Kodiak Island. These findings illustrate the dynamic, localized 462 complexity of emergent forearc deformation in response to the variation in orientation and 
463 character of subducting slabs. The results also suggest that the Kenai Mountains are an unusual

464 orogen that is in disequilibrium with the local erosional setting, presumably due to recent onset

465 or acceleration of surface uplift. Despite the potential for aggressive glacial erosion given the

466 local climate, erosion significantly lags behind rock uplift.

467

468 Acknowledgments

469 We thank Jeanette Arkle and Michelle Fame for helpful discussions and Jon Smith for 470 assistance with lab work and sample preparation. We want to thank Peter Haeussler and Terry

471 Pavlis for their helpful and thorough reviews of this manuscript. Support was provided by the

472 National Science Foundation grant EAR-1123688/1123643.

473

474

475

476

477

478

479

480

481

482

483

484

485

486 
487

\section{References}

Abers, G. A. (2008). Orogenesis from subducting thick crust and evidence from Alaska. Active Tectonics and Seismic Potential of Alaska,179, 337-349: American Geophysical Union Monograph Series.

Arkle, J., Armstrong, P., Haeussler, P., Prior, M., Hartman, S., Sendziak, K., \& Brush, J. (2013). Focused exhumation in the syntaxis of the western Chugach Mountains and Prince William Sound, Alaska. Geological Society of America Bulletin, 125(5-6), 776-793. doi: 10.1130/b30738.1

Berger, A. L., Spotila, J. A., Chapman, J. B., Pavlis, T. L., Enkelmann, E., Ruppert, N. A., \&Buscher, J. T. (2008). Architecture, kinematics, and exhumation of a convergent orogenic wedge: A thermochronological investigation of tectonic-climatic interactions within the central St. Elias orogen, Alaska. Earth and Planetary Science Letters, 270(1-2), 13-24. doi: http://dx.doi.org/10.1016/j.eps1.2008.02.034.

Bol, A. J. and Roeske, S. (1993). Strike-slip faulting and block rotation along the Contact fault system, Prince William sound Alaska. Tectonics, 12(1), 49-62.

Bradley, D. C., Parrish, R., Clendenen, W., Lux, D., Layer, P., Heizler, M., \& Donley, D. T. (2000). New geochronological evidence for the timing of early Tertiary ridge subduction in southern Alaska. US Geological Survey Professional Paper, 1615, 5-21.

Brandon, M. T., Roden-Tice, M. K., \&Garver, J. I. (1998). Late Cenozoic exhumation of the Cascadia accretionary wedge in the Olympic Mountains, northwest Washington State. Geological Society of America Bulletin, 110(8), 985-1009.

Brown, R. W., Beucher, R., Roper, S., Persano, C., Stuart, F., \& Fitzgerald, P. (2013). Natural age dispersion arising from the analysis of broken crystals. Part I: Theoretical basis and 
implications for the apatite (U-Th)/He thermochronometer. Geochimica et CosmochimicaActa, 122(0), 478-497. doi;10.1016/j.gca.2013.05.041.

512 Bruhn, R., \& Haeussler, P. (2006). Deformation driven by subduction and microplate collision:

513 Geodynamics of Cook Inlet basin, Alaska. Geological Society of America Bulletin, 118(3-4), 514 289-303. doi: 10.1130/b25672.1.

515 Bruhn, R., Pavlis, T., Plafker, G., \&Serpa, L. (2004). Deformation during terrane accretion in the 516 Saint Elias orogen, Alaska. Geological Society of America Bulletin, 116(7-8), 771-787. doi:

$517 \quad 10.1130 / \mathrm{b} 25182.1$

518 Buscher, J. T., Berger, A. L., \& Spotila, J. A. (2008). Exhumation in the Chugach-Kenai 519 Mountain Belt Above the Aleutian Subduction Zone, Southern Alaska.Active Tectonics and 520 Seismic Potential of Alaska,179, 151-166: American Geophysical Union Monograph Series. 521 Clendenen, W. S., Fisher, D., \& Byrne, T. (2003). Cooling and exhumation history of the Kodiak 522 accretionary prism, southwest Alaska. Special Papers-Geological Society of America, 71-88.

523 Cohen, S. C., \& J. T. Freymueller (1997). Deformation of the Kenai Peninsula, Alaska, $J$.

524 Geophys. Res.,102(B9), 20479-20487, doi:10.1029/97JB01513.

525 Christeson, G., Gulick, S., van Avendonk, H., Worthington, L., Reece, R., \& Pavlis, T. (2010).

526 The Yakutat terrane: Dramatic change in crustal thickness across the Transition fault, Alaska.

527 Geology, 38(10), 895-898. doi: 10.1130/g31170.1.

528 DeMets, C., Gordon, R. G., Argus, D. F., \& Stein, S. (1990). Current plate motions. Geophysical 529 Journal International, 101, 425-478.

530 Dominguez, S., Malavieille, J., \&Lallemand, S. E. (2000). Deformation of accretionary wedges 531 in response to seamount subduction: Insights from sandbox experiments. Tectonics, 19(1), 182532196. 
533 Ducea, M., Kidder, S., Chesley, J., \&Saleeby, J. (2009). Tectonic underplating of trench

534 sediments beneath magmatic arcs: the central California example. International Geology

535 Review, 51(1), 1-26. doi: 10.1080/00206810802602767.

536 Dumitru, T. A., Gans, P. B., Foster, D. A., \& Miller, E. L. (1991). Refrigeration of the western

537 Cordilleran lithosphere during Laramide shallow-angle subduction. Geology, 19(11), 1145-

5381148.

539 Eberhart-Phillips, D., Christensen, D. H., Brocher, T. M., Hansen, R., Ruppert, N. A., Haeussler,

540 P. J., \&Abers, G. A. (2006). Imaging the transition from Aleutian subduction to Yakutat

541 collision in central Alaska, with local earthquakes and active source data. Journal of

542 Geophysical Research: Solid Earth, 111(B11). doi: 10.1029/2005JB004240.

543 Ehlers, T. A., \& Farley, K. A. (2003). Apatite (U-Th)/He thermochronometry: methods and 544 applications to problems in tectonic and surface processes. Earth and Planetary Science 545 Letters, 206(1-2), 1-14. doi:10.1016/S0012-821X(02)01069-5.

546 Elliott, J. L., Larsen, C. F.,Freymueller,J. T.,\& R. J. Motyka (2010). Tectonic block motion and 547 glacial isostatic adjustment in southeast Alaska and adjacent Canada constrained by GPS 548 measurements. J. Geophys. Res., 115, B09407, doi:10.1029/2009JB007139.

549 English, J. M., Johnston, S. T., \& Wang, K. (2003). Thermal modelling of the Laramide orogeny: 550 testing the flat-slab subduction hypothesis. Earth and Planetary Science Letters, 214(3-4), 551 619-632. doi:10.1016/S0012-821X(03)00399-6.

552 Enkelmann, E., P. O. Koons, T. L. Pavlis, B. Hallet, A. Barker, J. Elliott, J. I. Garver, S. P. S. 553 Gulick, R. M. Headley, G. L. Pavlis, et al. (2015). Cooperation among tectonic and surface 554 processes in the St. Elias Range, Earth's highest coastal mountains. Geophys. Res.

555 Lett., 42, 5838-5846, doi:10.1002/2015GL064727. 
556 Enkelmann, E., Zeitler, P. K., Garver, J. I., Pavlis, T. L., \& Hooks, B. P. (2010). The

557 thermochronological record of tectonic and surface process interaction at the Yakutat-North

558 American collision zone in southeast Alaska.American Journal of Science, 310(4), 231-260.

559 Farley, K. A. (2000). Helium diffusion from apatite: General behavior as illustrated by Durango

560 fluorapatite. J. Geophys. Res., 105(B2), 2903-2914, doi:10.1029/1999JB900348.

561 Ferguson, K., Armstrong, P., Arkle, J., \& Haeussler, P. (2015). Focused rock uplift above the 562 subduction décollement at Montague and Hinchinbrook Islands, Prince William Sound, 563 Alaska. Geosphere, 11(1), 144-159. doi: 10.1130/ges01036.1.

564 Ferris, A., Abers, G. A., Christensen, D. H., \&Veenstra, E. (2003). High resolution image of the 565 subducted Pacific (?) plate beneath central Alaska, 50-150 km depth. Earth and Planetary 566 Science Letters, 214(3-4), 575-588. doi:10.1016/S0012-821X(03)00403-5.

567 Finzel, E. S., Trop, J. M., Ridgway, K. D., \&Enkelmann, E. (2011). Upper plate proxies for flat568 slab subduction processes in southern Alaska. Earth and Planetary Science Letters, 303(3-4), 569 348-360. doi:10.1016/j.eps1.2011.01.014.

570 Fisher, D. M., Gardner, T. W., Marshall, J. S., Sak, P. B., \&Protti, M. (1998). Effect of 571 subducting sea-floor roughness on fore-arc kinematics, Pacific coast, Costa 572 Rica. Geology, 26(5), 467-470.

573 Fisher, M. A., \&Magoon, L. B. (1978). Geologic framework of lower Cook inlet, Alaska. AAPG $574 \quad$ Bulletin, 62(3), 373-402.

575 Fletcher, H. J., \& Freymueller, J. T. (1999). New GPS constraints on the motion of the Yakutat 576 block. Geophysical Research Letters, 26(19), 3029-3032. 
577 Flowers, R. M., Ketcham, R. A., Shuster, D. L., \& Farley, K. A. (2009). Apatite (U-Th)/He

578 thermochronometry using a radiation damage accumulation and annealing model. Geochimica 579 et CosmochimicaActa, 73(8), 2347-2365. doi:10.1016/j.gca.2009.01.015.

580 Freeland, G. L., \& Dietz, R. S. (1973). Rotation history of Alaskan tectonic blocks.

581 Tectonophysics, 18(3-4), 379-389. doi:10.1016/0040-1951(73)90054-1.

582 Freymueller, J. T., Woodard, H., Cohen, S. C., Cross, R., Elliott, J., Larsen, C. F., Hreinsdóttir, 583 S., \&Zweck, C. (2008). Active Deformation Processes in Alaska, Based on 15 Years of GPS 584 Measurements.Active Tectonics and Seismic Potential of Alaska, (pp. 1-42):American 585 Geophysical Union Geophysics Monograph Series 179.

586 Fruehn, J., von Huene, R., \& Fisher, M. A. (1999). Accretion in the wake of terrane collision:

587 The Neogene accretionary wedge off Kenai Peninsula, Alaska. Tectonics, 18(2), 263-277. doi: 588 10.1029/1998TC900021

589 Fuis, G., Moore, T., Plafker, G., Brocher, T., Fisher, M., Mooney, W., Nokleberg, W., Page, R., 590 Beaudoin, B., Christensen, N., Levander, A., Lutter, W., Saltus, R., \&Ruppert, N. (2008). 591 Trans-Alaska Crustal Transect and continental evolution involving subduction underplating 592 and synchronous foreland thrusting. Geology, 36(3), 267-270. doi: 10.1130/g24257a.1.

593 Gardner, T., Fisher, D., Morell, K., \& Cupper, M. (2013). Upper-plate deformation in response 594 to flat slab subduction inboard of the aseismic Cocos Ridge, Osa Peninsula, Costa Rica. 595 Lithosphere, 5(3), 247-264. doi: 10.1130/1251.1.

596 Gutscher, M. A., Maury, R., Eissen, J. P., \& Bourdon, E. (2000). Can slab melting be caused by 597 flat subduction? Geology, 28(6), 535-538. doi: 10.1130/0091-

$598 \quad 7613(2000) 28 \& 1 t ; 535:$ csmbcb\&gt;2.0.co;2. 
Haeussler, P. J. (2008). An Overview of the Neotectonics of Interior Alaska: Far-Field Deformation from the Yakutat Microplate Collision.Active Tectonics and Seismic Potential of Alaska, (pp. 83-108): American Geophysical Union Geophysics Monograph Series 179. Haeussler, P., Bradley, D., Wells, R., \& Miller, M. (2003). Life and death of the Resurrection plate: Evidence for its existence and subduction in the northeastern Pacific in PaleoceneEocene time. Geological Society of America Bulletin, 115(7), 867-880. doi: 10.1130/00167606(2003)115\&lt;0867:ladotr\&gt;2.0.co;2.

Haeussler, P., Bruhn, R., \& Pratt, T. (2000). Potential seismic hazards and tectonics of the upper Cook Inlet basin, Alaska, based on analysis of Pliocene and younger deformation. Geological Society of America Bulletin, 112(9), 1414-1429. doi: 10.1130/00167606(2000)112\&lt;1414:pshato\&gt;2.0.co;2.

Haeussler, P. J., Armstrong, P. A., Liberty, L. M., Ferguson, K. M., Finn, S. P., Arkle, J. C., \& Pratt, T. L. (2015). Focused exhumation along megathrust splay faults in Prince William Sound, Alaska. Quaternary Science Reviews,113, 8-22.

Haeussler, P. J., \&Saltus, R. W. (2011). Location and extent of Tertiary structures in Cook Inlet Basin, Alaska, and mantle dynamics that focus deformation and subsidence (No. 1776-D, pp. i26). US Geological Survey.

Hartman, D. C., Pessel, G. H., \& McGee, D. L. (1974). Stratigraphy of the Kenai Group, Cook Inlet. Alaska Division of Geological and Geophysical Surveys, Alaska Open File Report, 49. Headley, R. M., Enkelmann, E., \&Hallet, B. (2013). Examination of the interplay between glacial processes and exhumation in the Saint Elias Mountains, Alaska. Geosphere, 9(2), 229241. 
621 Helwig, J.,\& Emmet, P. (1981). Structure of the Early Tertiary Orca Group in Prince William

622 Sound and some implications for the plate tectonic history of southern Alaska. Journal of the 623 Alaska Geological Society, 1, 12-35.

624 Karlstrom, T. N. V. (1961). The glacial history of Alaska: it's bearing on paleoclimatic history. 625 Annals of the New York Academy of Sciences, 95(1), 290-340. doi: 10.1111/j.1749-

$626 \quad$ 6632.1961.tb50040.x.

627 Kirschner, C. E., \& Lyon, C. A. (1973). Stratigraphic and Tectonic Development of Cook Inlet 628 Petroleum Province: Regional Arctic Geology of Alaska. 396-407.

629 Koppes, M., \&Hallet, B. (2006). Erosion rates during rapid deglaciation in Icy Bay, 630 Alaska. Journal of Geophysical Research: Earth Surface, 111(F2).

631 Li, Z. X., \&Li, X. H. (2007). Formation of the 1300-km-wide intracontinentalorogen and 632 postorogenic magmatic province in Mesozoic South China: A flat-slab subduction model. 633 Geology, 35(2), 179-182. doi: 10.1130/g23193a.1.

634 Little, T. A., \&Naeser, C. W. (1989). Tertiary tectonics of the Border Ranges Fault System, 635 Chugach Mountains, Alaska: Deformation and uplift in a forearc setting. J. Geophys. 636 Res., 94(B4), 4333-4359, doi:10.1029/JB094iB04p0433.

637 Magoon, L.B., (1986). Present-Day Geothermal Gradient.U.S. Geological Survey Bulletin, (B638 1596), 41-46.

639 Mankhemthong, N., Doser, D. I., \& Pavlis, T. L. (2013). Interpretation of gravity and magnetic 640 data and development of two-dimensional cross-sectional models for the Border Ranges fault 641 system, south-central Alaska.Geosphere, 9(2), 242-259.

642 Mann, D. H., \&Peteet, D. M. (1994). Extent and Timing of the Last Glacial Maximum in $643 \quad$ Southwestern Alaska. Quaternary Research, 42(2), 136-148. doi: 10.1006/qres.1994.1063 
644 Mazzotti, S., \& Hyndman, R. (2002). Yakutat collision and strain transfer across the northern

645 Canadian Cordillera. Geology, 30(6), 495-498. doi: 10.1130/0091-

646 7613(2002)030\&lt;0495:ycasta\&gt;2.0.co;2.

647 National Climate Data Center. 2005. Kenai municipal airport weather station data [online].

648 Available fromhttp://www.ncdc.noaa.gov/cdo-web/quickdata[cited 16December 2015]

649 National Climate Data Center. 2007. Seward meterological station [online]. Available from

650 http://www.ncdc.noaa.gov/cdo-web/quickdata [cited 16 December 2015]

651 Oskin, M., \& Burbank, D. W. (2005). Alpine landscape evolution dominated by cirque

652 retreat. Geology, 33(12), 933-936.

653 Ouimet, W. B., Whipple, K. X., \& Granger, D. E. (2009). Beyond threshold hillslopes: Channel

654 adjustment to base-level fall in tectonically active mountain ranges. Geology, 37(7), 579-582.

655 Parry, W. T., Bunds, M. P., Bruhn, R. L., Hall, C. M., \& Murphy, J. M. (2001). Mineralogy,

656 40Ar/39Ar dating and apatite fission track dating of rocks along the Castle Mountain fault,

657 Alaska. Tectonophysics, 337(3-4), 149-172. doi: 10.1016/S0040-1951(01)00117-2.

658 Pavlis, T. L., \& Bruhn, R.L. (1983). Deep-seated flow as a mechanism for the uplift of broad

659 forearc ridges and its role in the exposure of high P/T

660 metamorphicterranes.Tectonics, 2(5), 473-497, doi:10.1029/TC002i005p00473.

661 Pavlis, T. L., Picornell, C., Serpa, L., Bruhn, R. L., \& Plafker, G. (2004). Tectonic processes

662 during oblique collision: Insights from the St. Elias orogen, northern North American

663 Cordillera. Tectonics, 23(3).

664 Pavlis, T. L., \& Roeske, S. M. (2007). The Border Ranges fault system, southern

665 Alaska. Geological Society of America Special Papers, 431, 95-127. 
666

667

668

669

670

671

672

673 674 Printing Office.

675

676

677

678

679

680

681

682

683

684

685

686

687

688 835,145 .

Peacock, S. M., Thermal and petrologic structure of subduction zones, in Subduction: Top to Bottom, 119-133, AGU Geophysical Monograph 96, Washington, D.C., 1996.

Perry, S. E., Garver, J. I., \& Ridgway, K. D. (2009). Transport of the Yakutat Terrane, Southern Alaska: Evidence from Sediment Petrology and Detrital Zircon Fission-Track and U/Pb Double Dating. The Journal of Geology, 117(2), 156-173. doi: 10.1086/596302.

Péwé, T.L., (1975). Quaternary Geology of Alaska.U.S. Geological Survey Professional Paper,

Plafker, G. (1969). Tectonics of the March 27, 1964, Alaska earthquake (p. 74). US Government

Plafker, G., (1987). Regional geology and petroleum potential of the northern Gulf of Alaska continental margin.in Scholl, D.W., Grantz, A., and Vedder, J.G., eds., Geology and Resource Potential of the Continental Margin of Western North America and Adjacent Ocean BasinsBeaufort Sea to Baja California: Circum-PacificCouncil for Energy and Mineral Resources, Earth Sciences Series, 6, 299-268.

Plafker, G., and Berg, H.C., (1994). Overview of the geology and tectonic evolution of Alaska.in Plafker, G., and Berg, H.C., eds., The Geology of Alaska: Boulder, Colorado, Geological Society of America, Geology of North America, G-1, 989-1021.

Plafker, G., Nokleberg, W.J., \&Lull, J.S. (1989). Bedrock geology and tectonic evolution of the Wrangellia, Peninsular, and Chugach Terranes along the Trans-Alaska Crustal Transect in the Chugach Mountains and Southern Copper River Basin, Alaska, J. Geophys. Res., 94(B4), 4255-4295, doi:10.1029/JB094iB04p04255.

Plattner, C., Malservisi, R., Dixon, T. H., LaFemina, P., Sella, G. F., Fletcher, J., \& SuarezVidal, F. (2007). New constraints on relative motion between the Pacific Plate and Baja 
California microplate (Mexico) from GPS measurements. Geophysical Journal International, 170(3), 1373-1380. doi: 10.1111/j.1365-246x.2007.03494.x.

691 Ramos, V. A., Cristallini, E. O., \& Pérez, D. J. (2002). The Pampean flat-slab of the Central 692 Andes. Journal of South American Earth Sciences, 15(1), 59-78. doi:10.1016/S0895$6939811(02) 00006-8$.

694 Reece, R. S., Gulick, S. P., Horton, B. K., Christeson, G. L., \& Worthington, L. L. (2011).

695 Tectonic and climatic influence on the evolution of the Surveyor Fan and Channel system, Gulf 696 of Alaska. Geosphere, 7(4), 830-844.

697 Riccio, S. J., Fitzgerald, P.G., Benowitz, J.A., \& Roeske, S.M., (2014). The role of thrust 698 faulting in the formation of the eastern Alaska Range: Thermochronological constraints from 699 the Susitna Glacier Thrust Fault region of the intracontinental strike-slip Denali Fault $700 \quad$ system. Tectonics, 33, 2195-2217, doi:10.1002/2014TC003646.

701 Ridgway, K., Thoms, E., Layer, P., Lesh, M., White, J., \& Smith, S. (2007).

702 Neogenetranspressional foreland basin development on the north side of the central Alaska 703 Range, Usibelli Group and Nenana Gravel, Tanana basin. Geological Society of America $704 \quad$ Special Papers, 431, 507-547. doi: 10.1130/2007.2431(20).

705 Ridgway, K. D., Trop, J. M., \& Finzel, E. S. (2011). Modification of Continental Forearc Basins 706 by Flat-Slab Subduction Processes: A Case Study from Southern Alaska.Tectonics of 707 Sedimentary Basins, (pp. 327-346): John Wiley \& Sons, Ltd.

708 Riihimaki, C. A., MacGregor, K. R., Anderson, R. S., Anderson, S. P., \& Loso, M. G. (2005). 709 Sediment evacuation and glacial erosion rates at a small alpine glacier. Journal of Geophysical 710 Research: Earth Surface, 110(F3). 
711 Sample, J. C., \& Moore, J. C. (1987). Structural style and kinematics of an underplated slate belt, 712 Kodiak and adjacent islands, Alaska. Geological Society of America Bulletin, 99(1), 7-20.

713 Spotila, J. A.,\&Berger, A. L. (2010). Exhumation at orogenicindentor corners under long-term 714 glacial conditions: Example of the St. Elias orogen, Southern Alaska. Tectonophysics, 490(3715 4), 241-256. doi: 10.1016/j.tecto.2010.05.015.

716 Spotila, J. A., Buscher, J. T., Meigs, A. J., \&Reiners, P. W. (2004). Long-term glacial erosion of 717 active mountain belts: example of the Chugach-St. Elias Range, Alaska. Geology, 32(6), 501718504.

719 Stephens, C. D., Page, R. A., \& Lahr, J. C. (1990). Reflected and mode-converted seismic waves 720 within the shallow Aleutian Subduction Zone, Southern Kenai Peninsula, Alaska. Journal of 721 Geophysical Research: Solid Earth, 95(B5), 6883-6897. doi: 10.1029/JB095iB05p06883

722 von Huene, R. V., \&Klaeschen, D. (1999). Opposing gradients of permanent strain in the 723 aseismic zone and elastic strain across the seismogenic zone of the Kodiak shelf and slope, $724 \quad$ Alaska. Tectonics, 18(2), 248-262.

725 Von Huene, R., Klaeschen, D., Gutscher, M., \&Fruehn, J. (1998). Mass and fluid flux during 726 accretion at the Alaskan margin. Geological Society of America Bulletin, 110(4), 468-482.

727 Westaway, R. (2006). Cenozoic cooling histories in the Menderes Massif, western Turkey, may 728 be caused by erosion and flat subduction, not low-angle normalfaulting.

729 Tectonophysics, 412(1), 1-25.

730 Wiles, G. C., Calkin, P. E., \& Post, A. (1995). Glacier Fluctuations in the Kenai Fjords, Alaska, 731 U.S.A.: An Evaluation of Controls on Iceberg-Calving Glaciers. Arctic and Alpine Research, 732 27(3), 234-245. doi: 10.2307/1551954 
733 Willis, J. B., Haeussler, P. J., Bruhn, R. L., \& Willis, G. C. (2007). Holocene slip rate for the 734 western segment of the Castle Mountain fault, Alaska. Bulletin of the Seismological Society of $735 \quad$ America, 97(3), 1019-1024.

736 Worthington, L. L., Van Avendonk, H. J. A., Gulick, S. P. S., Christeson, G. L., \& Pavlis, T. 737 L. (2012). Crustal structure of the Yakutat terrane and the evolution of subduction and collision 738 in southern Alaska. J. Geophys. Res., 117, B01102, doi:10.1029/2011JB008493.

739 Ye, S., Flueh, E.R., Kaeschen, D., and Von Huene, R.(1997). Crustal structure along the EDGE 740 transect beneath the Kodiak Shelf off Alaska derived from OBH seismic refraction data:

741 Geophysical Journal International., 130, 283-302. doi:10.1111/j.1365-246X.1997.tb05648.x.

742 Zhou, X. M., \& Li, W. X. (2000). Origin of Late Mesozoic igneous rocks in Southeastern China:

743 implications for lithosphere subduction and underplating of maficmagmas.

744 Tectonophysics, 326(3), 269-287.

745

746

747

748

749 


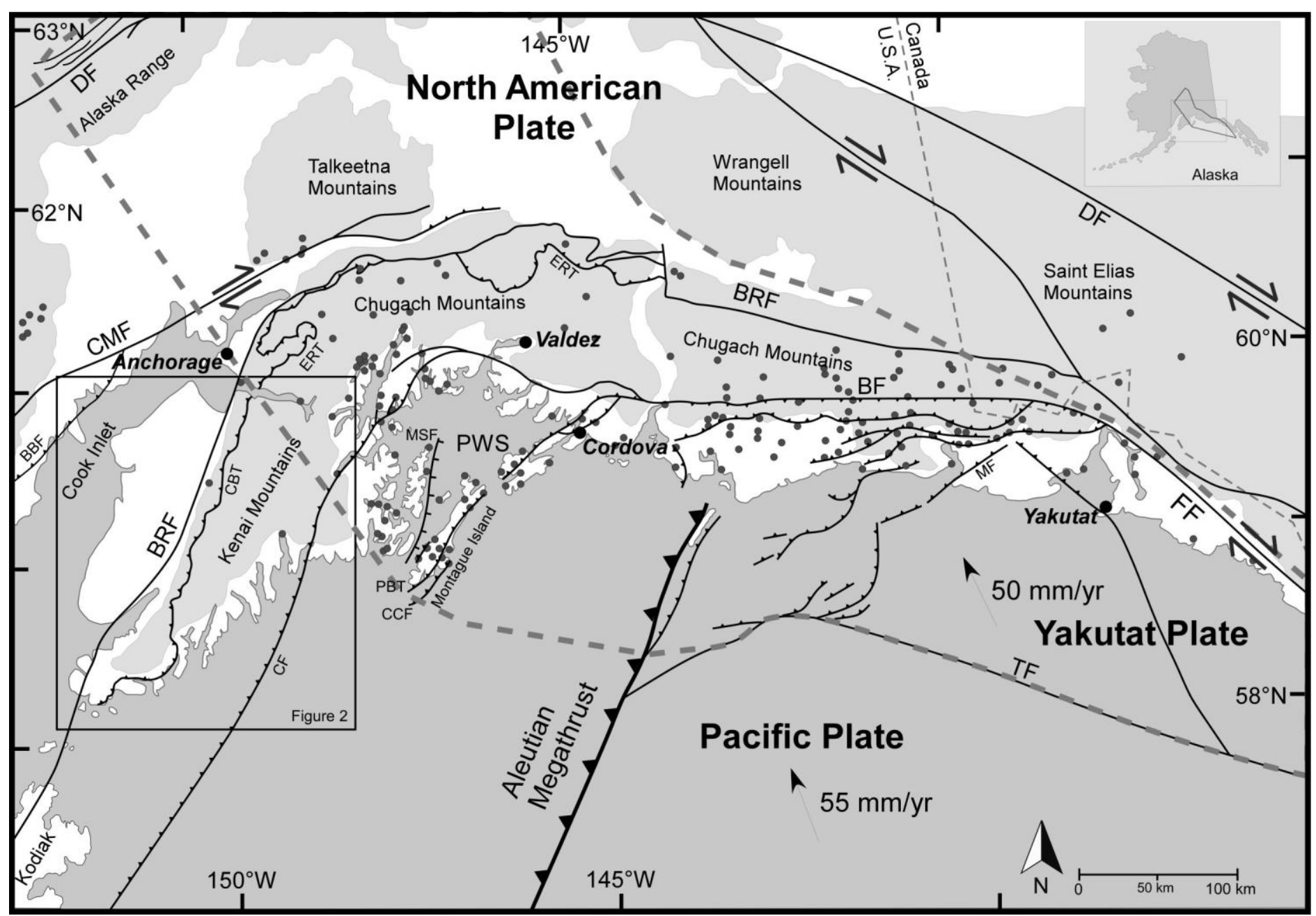

Figure 1: Generalized tectonic map of major orogens, faults and plate boundaries, and localities mentioned in text throughout south central Alaska. The grey dots depict the distribution of AHe ages from previous studies. Plate motion vectors are from

Elliott et al. (2010) for Yakutat Plate and Plattner et al. (2007) for the Pacific Plate. The thick grey dashed line shows the limit 

(thick) to relatively more minor (thinner) activity. BF = Bagley Fault, BRF $=$ Border Ranges Fault, $\mathrm{CCF}=\mathrm{Cape}$ Cleare Fault, $\mathrm{CMF}=$ Castle Mountain Fault, $\mathrm{CBT}=$ Chugach Bay Thrust, $\mathrm{CF}=$ Contact Fault, DF $=$ Denali Fault, ERT = Eagle River Thrust, FF = Fairweather Fault, MSF = Montague Strait Fault, PBT = Patton Bay Thrust, PWS = Prince William Sound. 


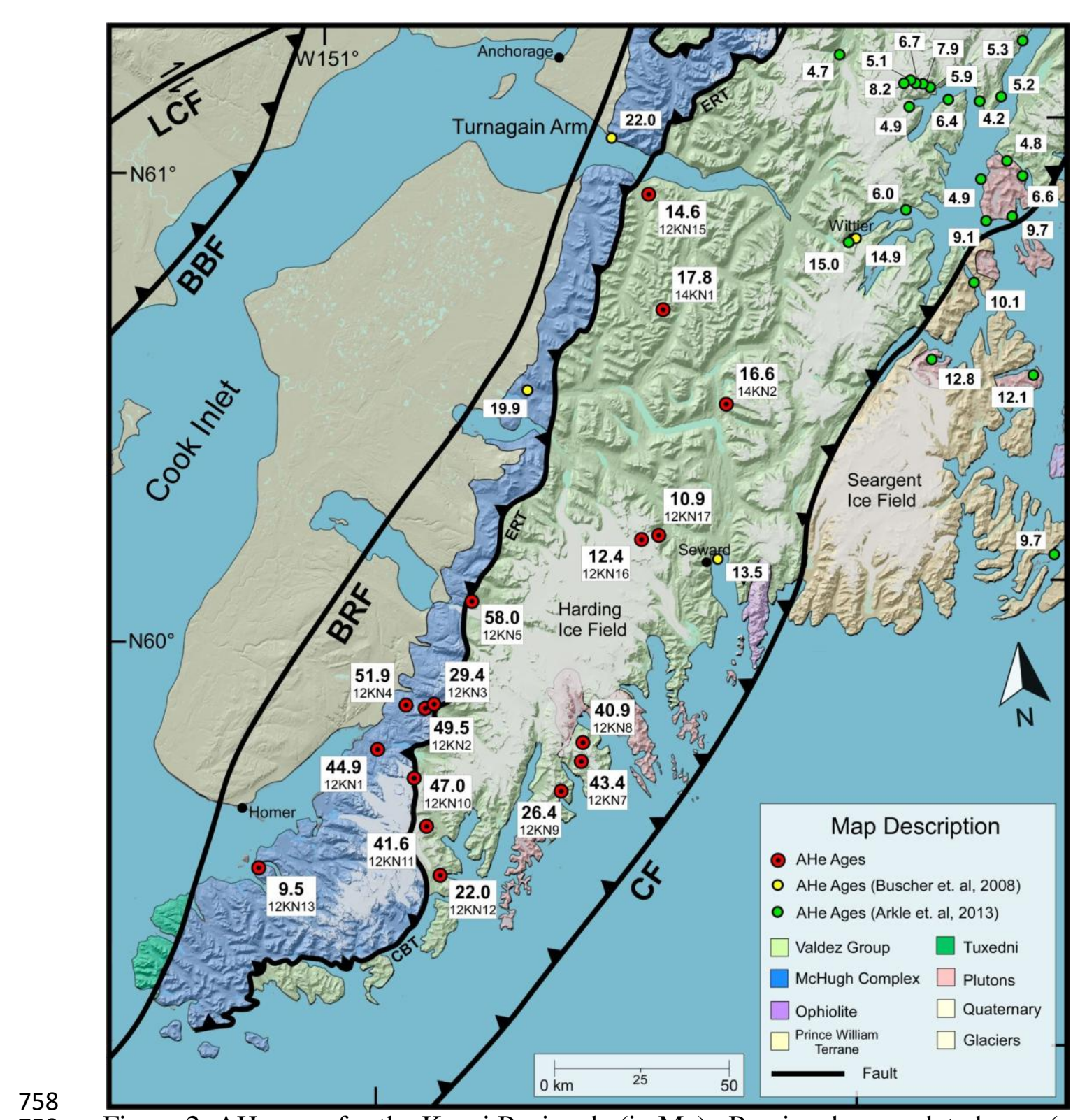

760 yellow circles) from other studies are included along with 17 new AHe ages (red circles).BBF =

761 Bruin Bay Fault, CF = Contact Fault, LCF = Lake Clark Fault. 


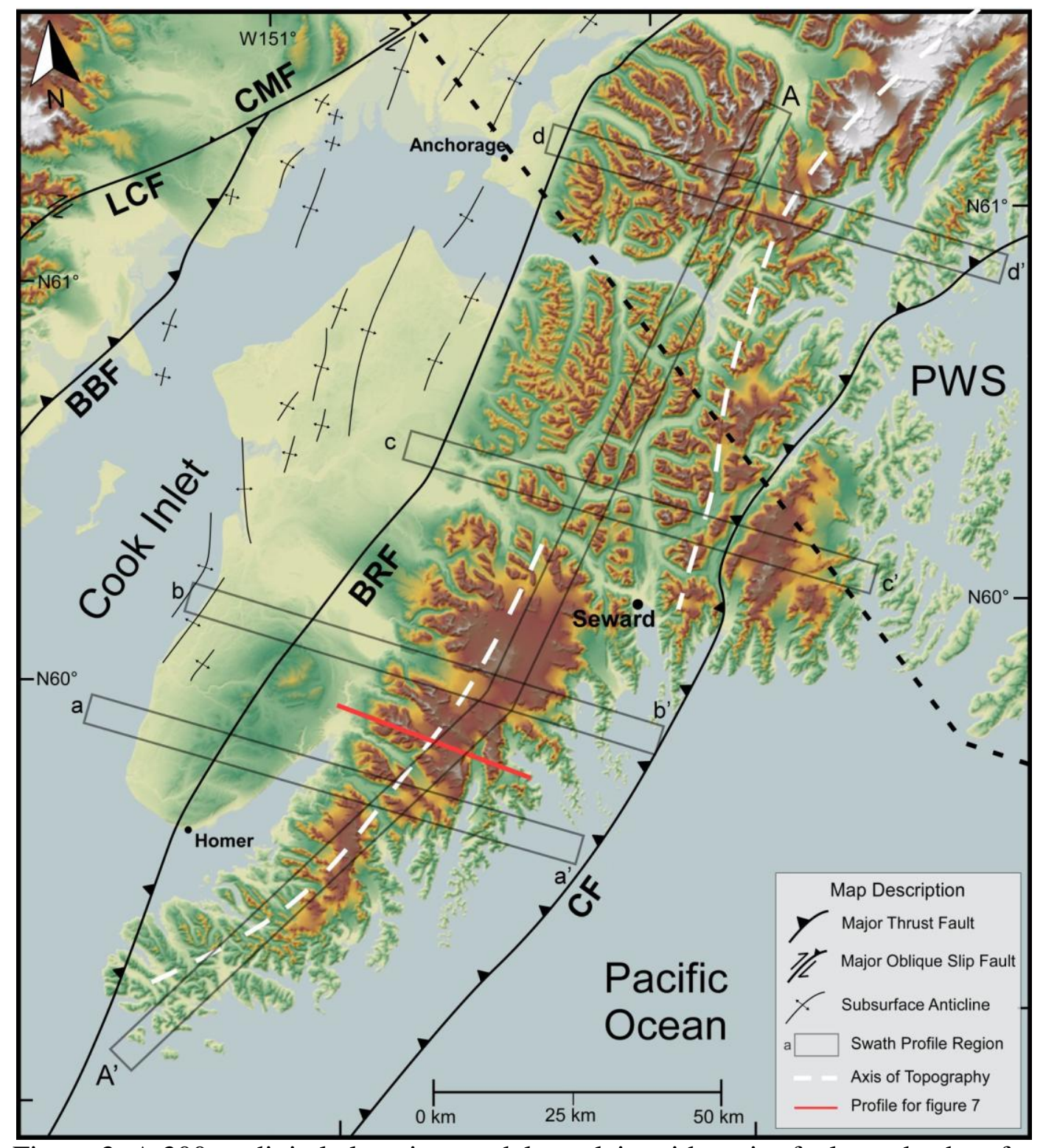

Figure 3: A 300-m digital elevation model overlain with major faults and subsurface anticlines.

764 Topography is similar in ruggedness to the Chugach Mountains (see text for details). The axis of

765 the mountain range shifts to the west south of Seward. The dashed line represents the location of

766 the subducted Yakutat slab beneath the region. Rectangles represent locations of swath profiles

767 depicted in figure 4. BRF = Border Ranges Fault, $\mathrm{BBF}=$ Bruin Bay Fault, $\mathrm{CMF}=\mathrm{Castle}$

768 Mountain Fault, $\mathrm{CF}=$ Contact Fault, $\mathrm{LCF}=$ Lake Clark Fault. 


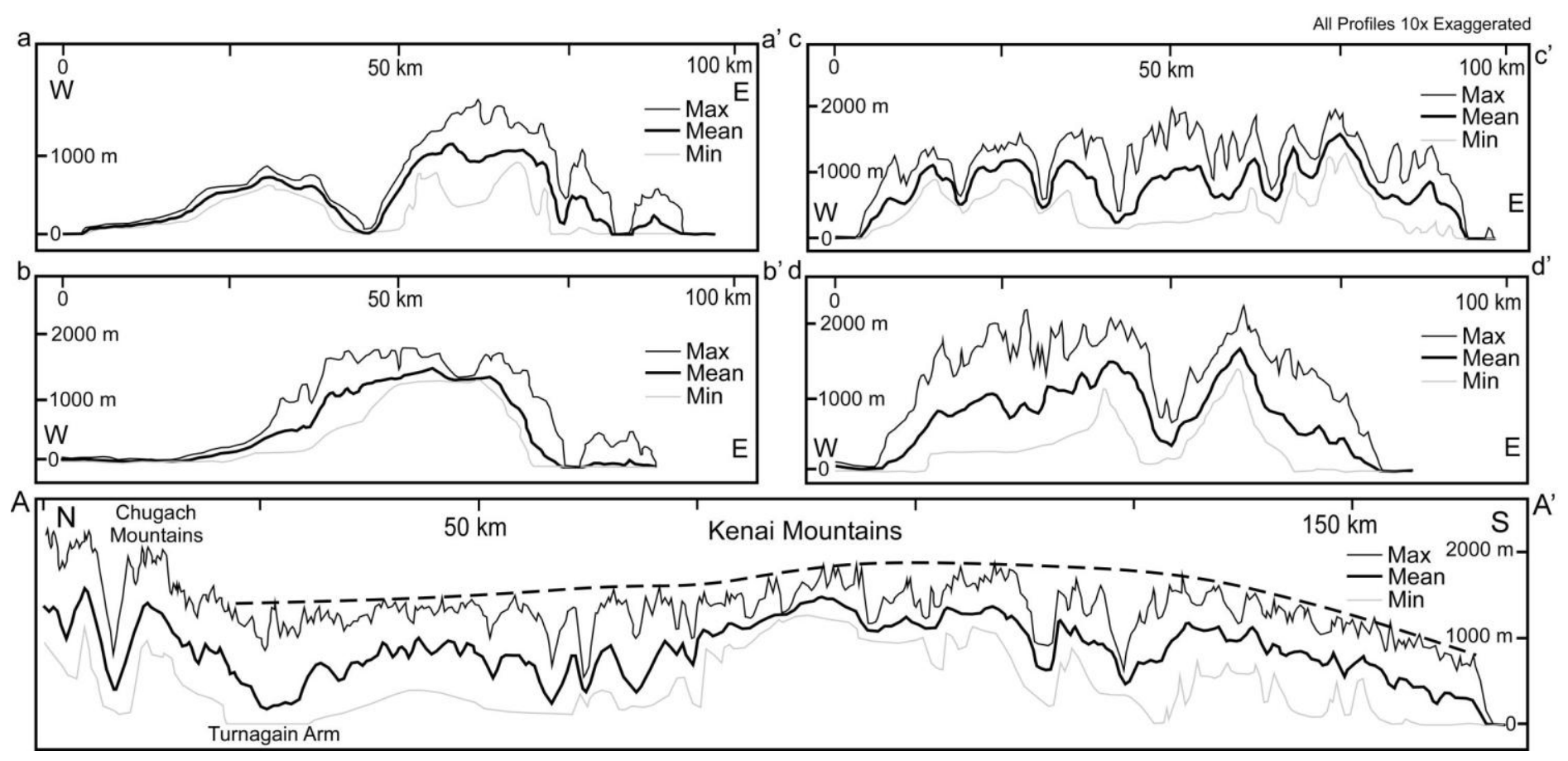

771 Figure 4: Swath profiles depicting topography across the Kenai Peninsula (a-d) and a long axis profile (A-A')downthe Kenai

772 Peninsula. See Figure 3 for the locations of the profiles. Profiles a-a' and b-b' show the dome like topography of the Harding Icefield

773 and the southern half of the Kenai Peninsula. Profile c-c' shows the unglaciated portion of the northern Kenai Peninsula. Profile d-d'

774 shows the higher and more deeply incised topography of the Chugach Mountains to the north. Profile A-A' shows the distinct

775 topographic characteristics that separate the Kenai Mountains from the Chugach Mountains and the concordant elevation of peaks and

776 ridges (black dashed line). 


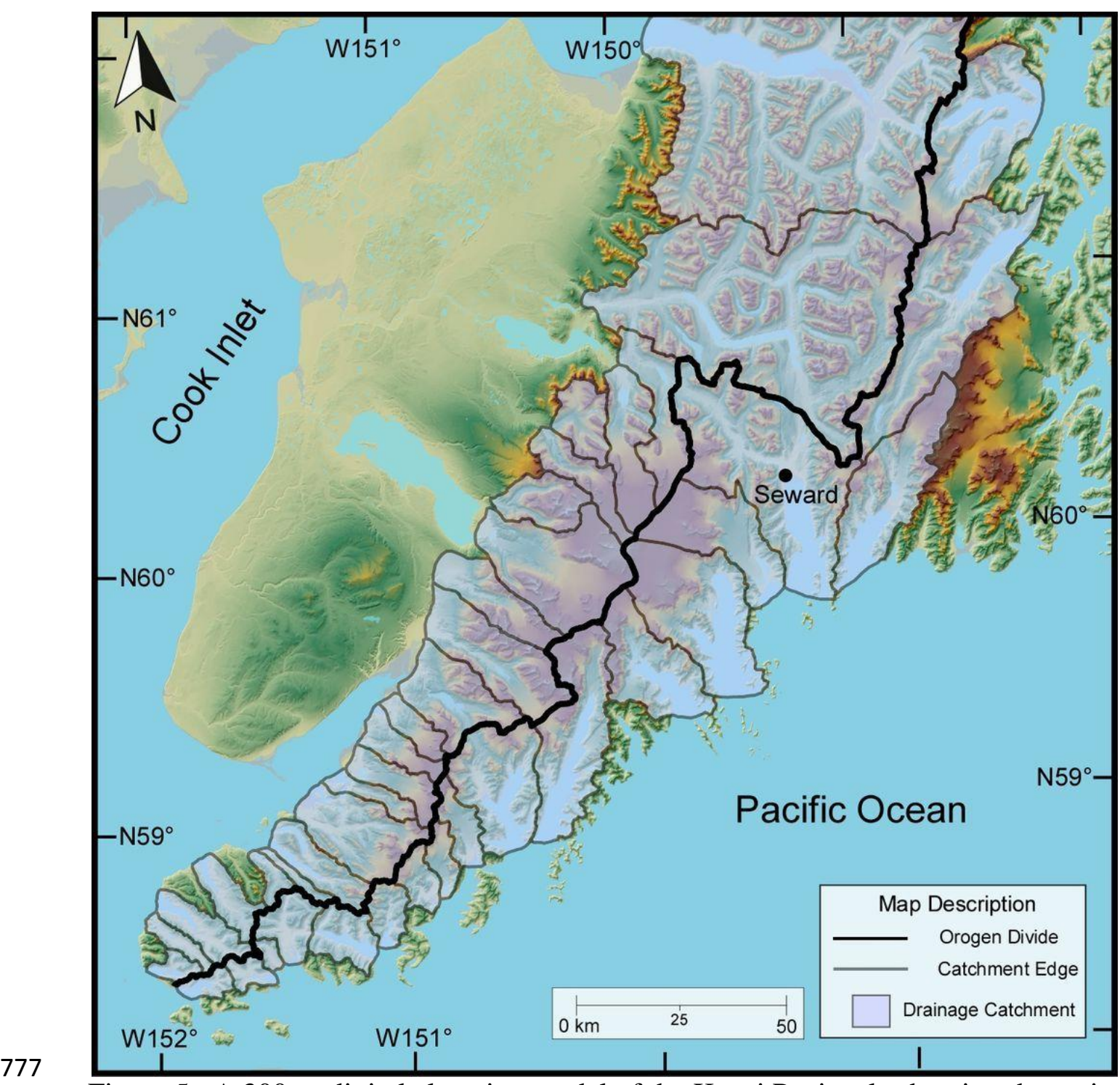

778 Figure 5: A 300-m digital elevation model of the Kenai Peninsula showing the main drainage

779 divide and individual catchments. The drainage divide follows the coast to the north, but steps

780 west south of Seward. Similarly, the drainage catchments are large $\left(1,600 \mathrm{~km}^{2}\right)$ north of Seward

781 and substantially smaller $\left(300 \mathrm{~km}^{2}\right)$ to the south. 

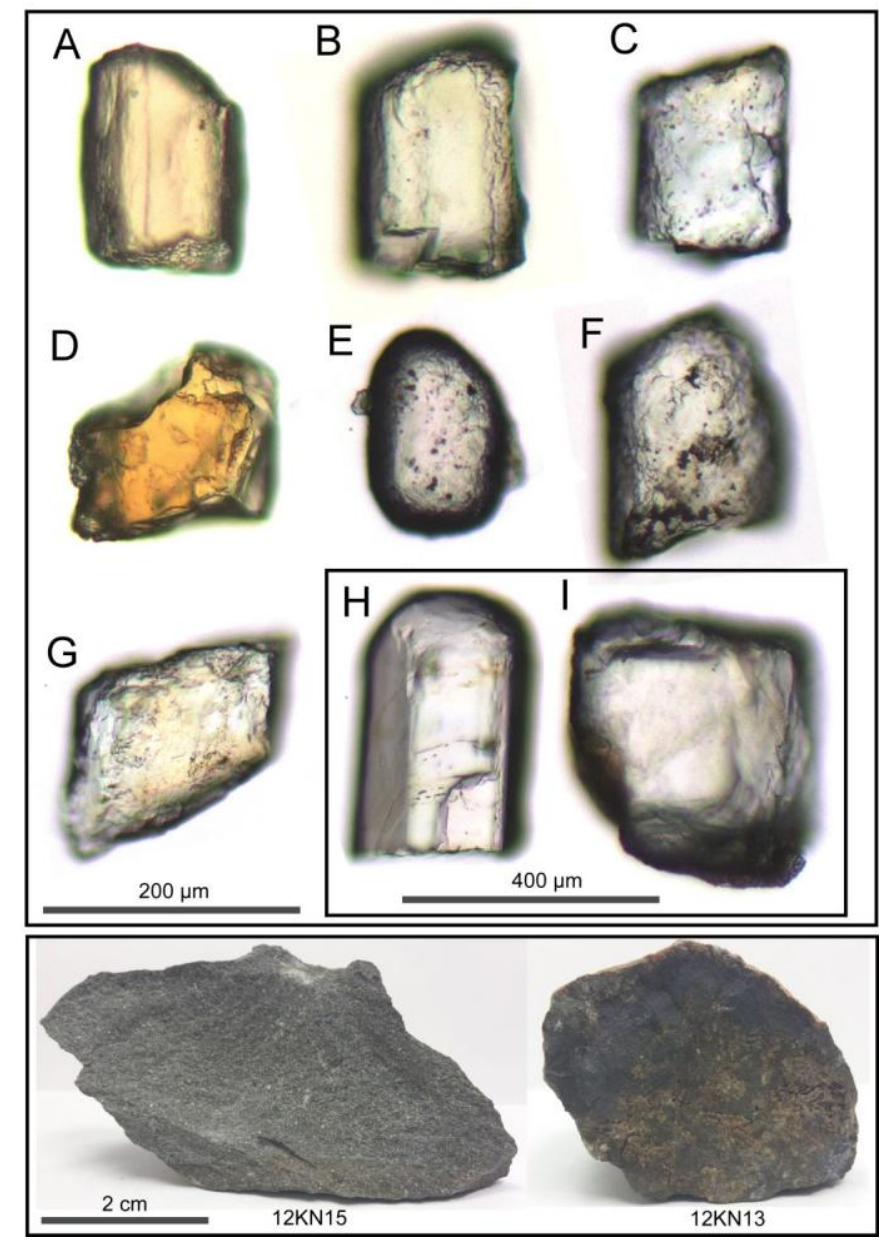

783 Figure 6: Apatite grains and hand samples depicting the range of samples used for analysis in

784 this study. Apatite grain A is an example of some of the best quality grains used for the study,

785 but this quality was rare. Apatites grains $\mathrm{B}$ and $\mathrm{C}$ are broken and have imperfections on their

786 surfaces, but still preserve crystal habit and are inclusion free. Apatite grain D is good quality but

787 fractured on many of the edges. Apatite grain E has worn edges and is frosted, suggesting that it

788 may have undergone transport and alteration before deposition. Apatites grains $\mathrm{F}$ and $\mathrm{G}$ are

789 examples of some of the lowest quality apatites used for this study. Apatite grains Hand I are

790 decent quality grains which are larger than $>100 \mu \mathrm{m}$ and were used as single grain aliquots, but

791 grains such as these often had internal flaws and non-birefringent microinclusions. Hand sample

792 12KN15 is an example of a coarser grained metasandstone that yielded apatite. Sample 12KN13 
793 is an example of the majority of samples for the Kenai Mountains, which is fine grained and 794 produced low quality apatite. 

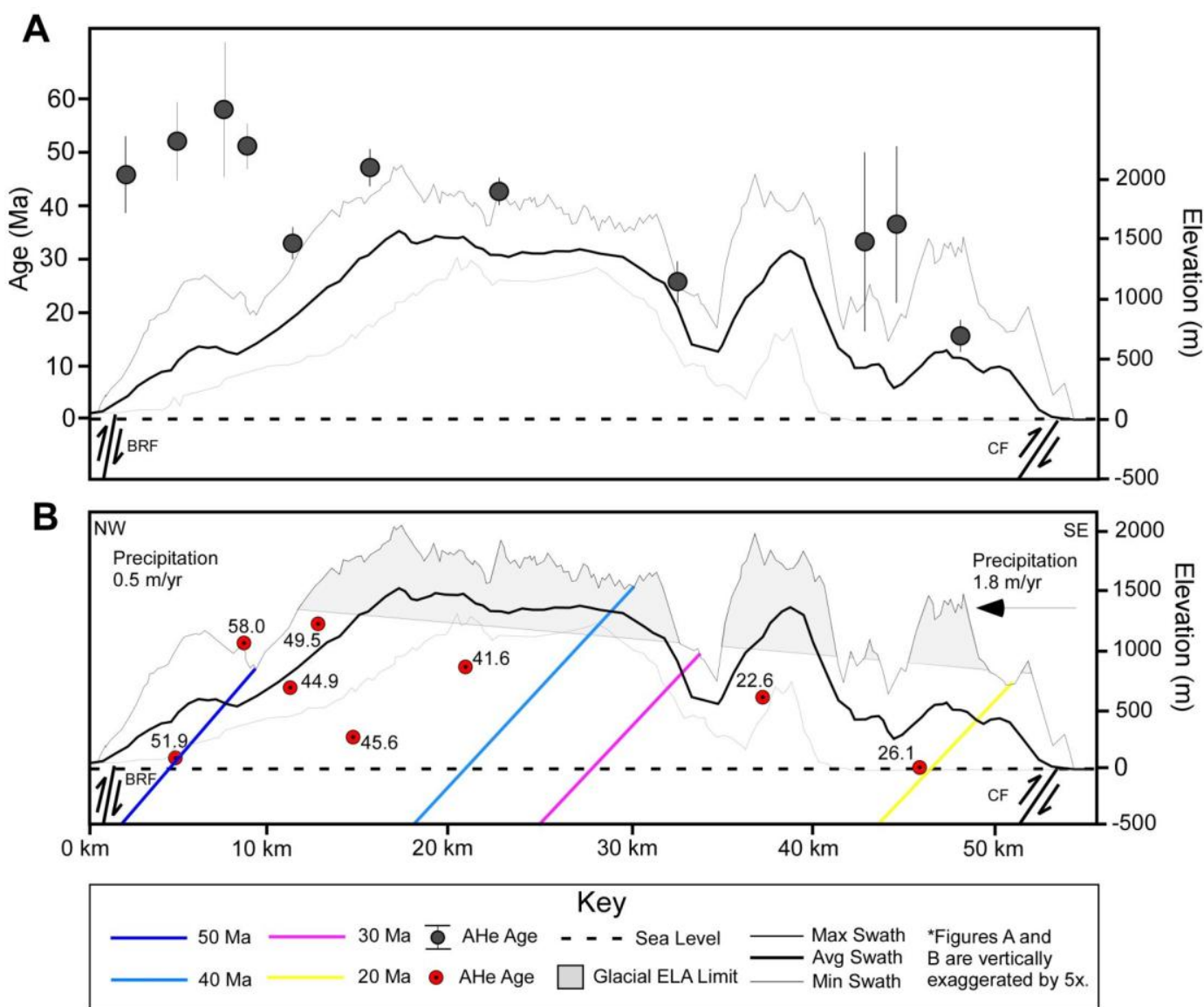

801 lowering towards the east due to precipitation gradient. $\mathrm{BRF}=$ Border Ranges Fault, $\mathrm{CF}=$

Figure 7: (A) AHe age vs. distance along swath topographic profiles along the Kenai Mountains.

The general trend of AHe ages shows a decrease towards the east and windward flank of the mountains. (B) Age distance plot with approximate AHe isochrons illustrating a potential PRZ tilted down to the west. Glacial ELA (Mann \& Peteet, 1994; Wiles et al., 1995) is shown Contact Fault. 


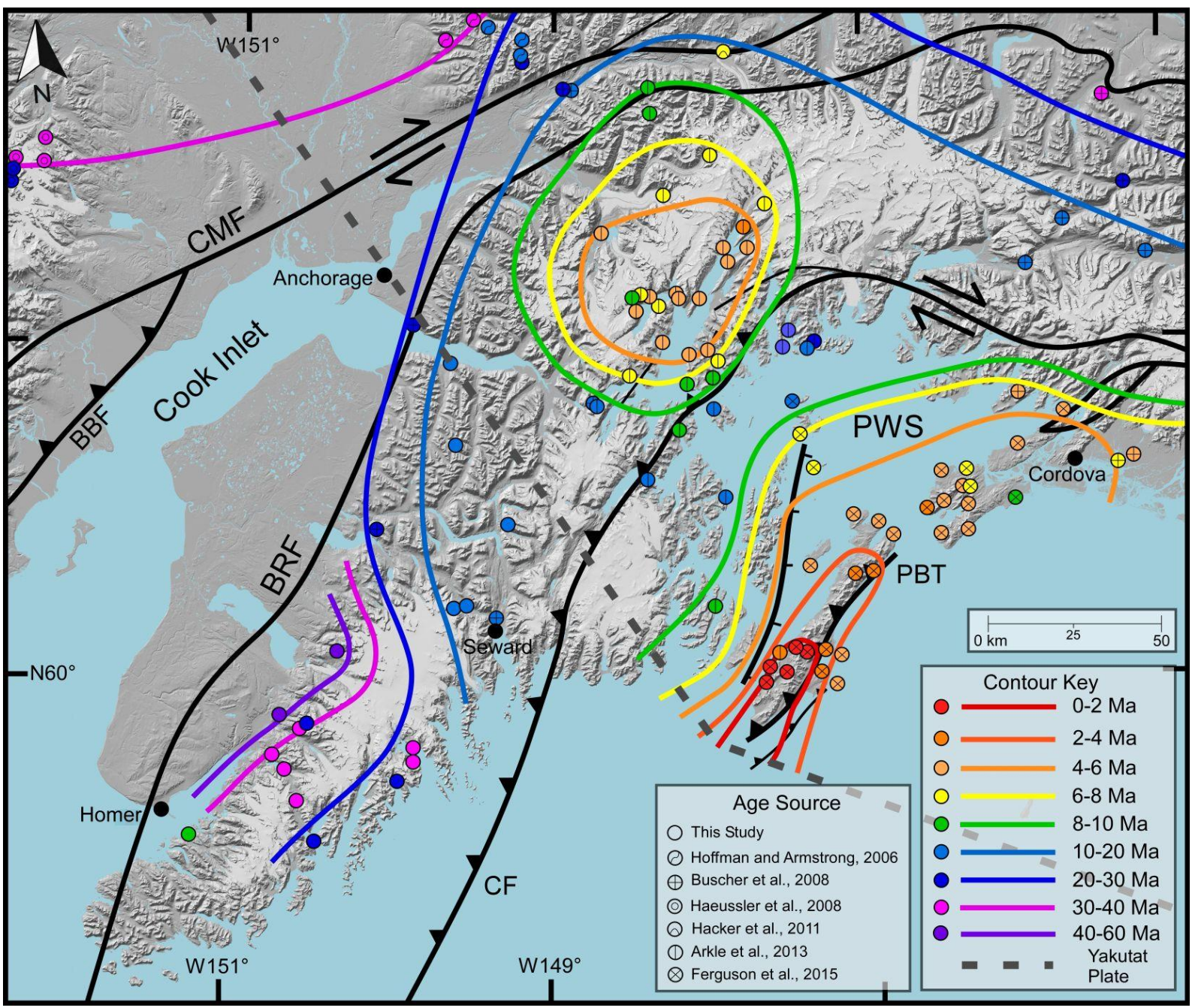

803

804

805

806

807

808

809

810

Figure 8: AHe age contour map for the Prince William Sound and surrounding coastal

mountains. The new AHe ages are the oldest in the region and portray a zone of slow

exhumation southwest of the edge of the Yakutat plate. The Chugach Core and the Patton Bay

Thrust regions have much faster exhumation rates due to upper plate deformation related to the

Yakutat plate. $\mathrm{BRF}=$ Border Ranges Fault, $\mathrm{BBF}=$ Bruin Bay Fault, $\mathrm{CMF}=$ Castle Mountain

Fault, CBT $=$ Chugach Bay Thrust, $\mathrm{CF}=$ Contact Fault $(\mathrm{Bol}$ and Roeske, 1993), ERT $=$ Eagle

River Thrust, $\mathrm{PBT}=$ Patton Bay Thrust. 


\begin{tabular}{|c|c|c|c|c|c|c|c|c|c|c|c|c|c|c|c|c|}
\hline Sample & $\begin{array}{l}\text { Elevation } \\
\text { (m) }\end{array}$ & Latitude & Longitude & Rock type & $\begin{array}{l}\text { Mass } \\
\text { (mg) }\end{array}$ & $\underset{(\mu \mathrm{m})}{\operatorname{mwar}}$ & $\begin{array}{c}\mathrm{He} \\
(\mathbf{p m o l})\end{array}$ & $\begin{array}{c}\mathbf{U} \\
(\mathbf{p p m})\end{array}$ & $\begin{array}{c}\text { Th } \\
\text { (ppm) }\end{array}$ & $\begin{array}{c}\text { Sm } \\
(\mathbf{p p m})\end{array}$ & $\mathrm{eU}$ & Grains & $\mathbf{F}_{T}$ & $\begin{array}{l}\text { Corr. Age } \\
\text { (Ma) }\end{array}$ & $\begin{array}{l}\text { Average Age } \\
\text { (Ma) }\end{array}$ & $\begin{array}{l}\text { Standard } \\
\text { Deviation }\end{array}$ \\
\hline \multirow[t]{8}{*}{ 12KN1 } & \multirow[t]{8}{*}{713} & \multirow[t]{8}{*}{59.7295} & \multirow[t]{8}{*}{-150.8627} & \multirow[t]{8}{*}{ meta. sand } & 0.0013 & 46.0 & 0.0022 & 8.3 & 16.4 & 141.6 & 12.8 & 1 & 0.68 & 40.1 & \multirow{8}{*}{$\begin{array}{c}\mathbf{4 4 . 9} \\
\mathrm{n}=8^{* *} \\
\mathrm{~N}=8^{* * *}\end{array}$} & \multirow{8}{*}{$\begin{array}{l}8.5 \mathrm{Ma} \\
19.0 \%\end{array}$} \\
\hline & & & & & 0.0018 & 50.6 & 0.0010 & 3.3 & 6.3 & 60.0 & 5.1 & 1 & 0.79 & 28.1 & & \\
\hline & & & & & 0.0022 & 32.2 & 0.0033 & 5.3 & 14.6 & 127.2 & 9.4 & 3 & 0.63 & 50.5 & & \\
\hline & & & & & 0.0137 & 47.2 & 0.0201 & 4.9 & 10.3 & 101.6 & 7.8 & 5 & 0.74 & 50.1 & & \\
\hline & & & & & 0.0065 & 69.0 & 0.0097 & 5.1 & 7.8 & 115.8 & 7.5 & 1 & 0.82 & 48.2 & & \\
\hline & & & & & 0.0044 & 55.2 & 0.0108 & 7.1 & 22.1 & 117.2 & 12.9 & 1 & 0.76 & 48.4 & & \\
\hline & & & & & 0.0111 & 46.4 & 0.0182 & 5.3 & 10.3 & 145.9 & 8.5 & 5 & 0.72 & 54.5 & & \\
\hline & & & & & 0.0113 & 38.0 & 0.0411 & 20.2 & 24.4 & 164.6 & 26.8 & 12 & 0.67 & 39.4 & & \\
\hline \multirow[t]{6}{*}{ 12KN2 } & \multirow[t]{6}{*}{1227} & \multirow[t]{6}{*}{59.8524} & \multirow[t]{6}{*}{-150.6686} & \multirow[t]{6}{*}{ graywacke } & 0.0023 & 64.4 & 0.0034 & 5.1 & 9.3 & 121.4 & 7.9 & 1 & 0.81 & 45.6 & \multirow{6}{*}{$\begin{array}{l}\mathbf{4 9 . 5} \\
\mathrm{n}=6 \\
\mathrm{~N}=6\end{array}$} & \multirow{6}{*}{$\begin{array}{c}3.8 \mathrm{Ma} \\
7.7 \%\end{array}$} \\
\hline & & & & & 0.0029 & 55.2 & 0.0037 & 4.1 & 9.3 & 115.7 & 6.9 & 1 & 0.81 & 46.6 & & \\
\hline & & & & & 0.0052 & 59.8 & 0.0069 & 4.3 & 9.0 & 153.0 & 7.2 & 1 & 0.80 & 47.1 & & \\
\hline & & & & & 0.0066 & 69.0 & 0.0086 & 3.8 & 6.3 & 152.0 & 6.1 & 1 & 0.81 & 55.4 & & \\
\hline & & & & & 0.0042 & 53.0 & 0.0076 & 5.4 & 12.6 & 161.2 & 9.2 & 2 & 0.76 & 52.5 & & \\
\hline & & & & & 0.0033 & 48.5 & 0.0051 & 4.7 & 13.5 & 183.8 & 8.8 & 4 & 0.71 & 49.7 & & \\
\hline \multirow[t]{5}{*}{$12 \mathrm{KN} 3$} & \multirow[t]{5}{*}{1568} & \multirow[t]{5}{*}{59.8607} & -150.6456 & graywacke & 0.0051 & 69.0 & 0.0274 & 29.7 & 43.3 & $\begin{array}{ll}107.8 \\
\end{array}$ & 40.4 & 1 & 0.82 & 31.1 & & \\
\hline & & & & & 0.0044 & 52.2 & 0.0059 & 3.8 & 10.8 & 146.6 & 7.1 & 2 & 0.76 & 50.7 & 29.4 & $2.3 \mathrm{Ma}$ \\
\hline & & & & & 0.0080 & 42.5 & 0.0366 & 14.7 & 8.0 & 279.5 & 18.0 & 7 & 0.69 & 74.3 & $\mathrm{n}=2$ & $8.0 \%$ \\
\hline & & & & & 0.0077 & 35.9 & 0.0197 & 21.3 & 22.5 & 215.0 & 27.7 & 7 & 0.65 & 27.7 & $\mathrm{~N}=4$ & \\
\hline & & & & & 0.0138 & 75.6 & 0.0352 & 2.1 & 6.1 & 118.2 & 4.1 & 2 & 0.83 & 223 & & \\
\hline $12 \mathrm{KN} 4$ & 99 & 59.8524 & -150.7424 & graywacke & 0.0055 & 34.7 & 0.0057 & 3.7 & 8.8 & 166.9 & 6.7 & 5 & 0.63 & 50.9 & & \\
\hline & & & & & 0.0057 & 36.8 & 0.0054 & 3.9 & 9.2 & 138.4 & 6.8 & 5 & 0.66 & 43.2 & 51.9 & 7.4 Ma \\
\hline & & & & & 0.0060 & 37.7 & 0.0181 & 4.2 & 9.7 & 146.6 & 7.2 & 5 & 0.66 & 130 & $\mathrm{n}=5$ & $14.3 \%$ \\
\hline & & & & & 0.0058 & 35.3 & 0.0070 & 4.4 & 10.8 & 162.4 & 7.7 & 6 & 0.63 & 50.6 & $\mathrm{~N}=6$ & \\
\hline & & & & & 0.0074 & 39.1 & 0.0112 & 4.3 & 9.6 & 169.3 & 7.4 & 6 & 0.66 & 63.8 & & \\
\hline & & & & & 0.0053 & 38.0 & 0.0094 & 6.2 & 14.8 & 197.0 & 10.6 & 5 & 0.67 & 50.7 & & \\
\hline 12KN5 & 1141 & 60.0678 & -150.4240 & meta. sand & 0.0030 & 39.8 & 0.0246 & 22.8 & 42.3 & 120.1 & 33.3 & 3 & 0.68 & 70.0 & & \\
\hline & & & & & 0.0091 & 78.2 & 0.0698 & 24.1 & 20.2 & 34.1 & 29.0 & 1 & 0.84 & 59.8 & 58.0 & $13.0 \mathrm{Ma}$ \\
\hline & & & & & 0.0102 & 101.2 & 0.3968 & 24.0 & 7.4 & 210.2 & 26.8 & 1 & 0.90 & 312 & $n=3$ & $22.4 \%$ \\
\hline & & & & & 0.0039 & 70.1 & 0.0010 & 1.2 & 0.4 & 42.3 & 1.5 & 2 & 0.83 & 44.1 & $\mathrm{~N}=4$ & \\
\hline $12 \mathrm{KN} 7$ & 598 & 59.7393 & -150.0264 & meta.sand & 0.0051 & 73.6 & 0.0128 & 5.6 & 12.6 & 219.1 & 9.6 & 1 & 0.86 & 62.5 & & \\
\hline & & & & & 0.0087 & 71.6 & 0.0292 & 8.7 & 17.1 & 183.7 & 13.6 & 2 & 0.82 & 59.6 & & \\
\hline & & & & & 0.0068 & 47.7 & 0.0210 & 41.1 & 22.6 & 194.5 & 47.4 & 3 & 0.77 & 16.4 & & \\
\hline & & & & & 0.0061 & 64.4 & $* 0.0001$ & 0.1 & 0.5 & 6.6 & 0.3 & 1 & 0.81 & 24.0 & 43.4 & 14.3 Ma \\
\hline & & & & & 0.0070 & 82.8 & $* 0.0002$ & 0.3 & 0.1 & 16.1 & 0.4 & 1 & 0.85 & 40.2 & $\mathrm{n}=10$ & $32.9 \%$ \\
\hline & & & & & 0.0077 & 87.4 & 0.0418 & 18.9 & 21.6 & 148.3 & 24.8 & 1 & 0.85 & 49.6 & $\mathrm{~N}=10$ & \\
\hline & & & & & 0.0128 & 101.2 & 0.0022 & 0.7 & 0.2 & 30.1 & 0.9 & 1 & 0.90 & 46.5 & & \\
\hline & & & & & 0.0079 & 52.8 & 0.0169 & 5.9 & 17.3 & 205.2 & 10.9 & 2 & 0.80 & 49.6 & & \\
\hline & & & & & 0.0035 & 55.4 & 0.0105 & 10.6 & 20.9 & 242.9 & 16.7 & 2 & 0.81 & 44.1 & & \\
\hline & & & & & 0.0044 & 68.8 & 0.0220 & 19.4 & 37.7 & 213.2 & 29.4 & 2 & 0.82 & 40.9 & & \\
\hline $12 \mathrm{KN8}$ & 10 & 59.7685 & -150.0314 & meta. sand & 0.0152 & 105.8 & 0.0064 & 0.9 & 0.3 & 3.8 & 1.0 & 1 & 0.88 & 93.8 & & \\
\hline & & & & & 0.0099 & 76.4 & 0.0810 & 45.7 & 17.1 & 135.9 & 50.4 & 2 & 0.82 & 38.0 & & \\
\hline & & & & & 0.0096 & 54.3 & 0.1408 & 73.7 & 8.4 & 197.5 & 76.6 & 3 & 0.78 & 47.4 & & \\
\hline & & & & & 0.0130 & 49.6 & 0.2988 & 42.5 & 5.5 & 127.4 & 44.4 & 8 & 0.73 & 136 & 40.9 & $11.7 \mathrm{Ma}$ \\
\hline & & & & & 0.0059 & 37.8 & 0.0589 & 52.6 & 7.3 & 179.0 & 55.2 & 4 & 0.68 & 51.6 & $\mathrm{n}=8$ & $28.7 \%$ \\
\hline & & & & & 0.0137 & 51.3 & 0.0058 & 6.0 & 1.3 & 39.4 & 6.5 & 6 & 0.74 & 17.1 & $\mathrm{~N}=10$ & \\
\hline & & & & & 0.0209 & 147.2 & 0.0194 & 4.4 & 0.6 & 35.1 & 4.7 & 1 & 0.93 & 42.1 & & \\
\hline
\end{tabular}




\begin{tabular}{|c|c|c|c|c|c|c|c|c|c|c|c|c|c|c|c|c|}
\hline & & & & & 0.0054 & 51.4 & 0.0348 & 30.9 & 6.3 & 143.4 & 33.1 & 3 & 0.77 & 49.7 & & \\
\hline & & & & & 0.0125 & 80.1 & 0.0213 & 11.3 & 2.4 & 28.1 & 12.0 & 2 & 0.86 & 31.8 & & \\
\hline & & & & & 0.0130 & 70.1 & 0.1225 & 42.3 & 4.0 & 143.8 & 44.0 & 2 & 0.84 & 49.5 & & \\
\hline \multirow[t]{7}{*}{$12 \mathrm{KN} 9$} & 1 & 59.6333 & -150.0969 & schist & 0.0015 & 48.5 & 0.0151 & 47.6 & 47.4 & 186.2 & 59.6 & 3 & 0.74 & 45.3 & & \\
\hline & & & & & 0.0087 & 72.8 & 0.0418 & 36.5 & 17.5 & 174.6 & 41.5 & 2 & 0.82 & 27.3 & & \\
\hline & & & & & 0.0027 & 51.0 & 0.0099 & 6.8 & 16.6 & 184.3 & 11.6 & 2 & 0.75 & 85.5 & 26.4 & $1.5 \mathrm{Ma}$ \\
\hline & & & & & 0.0082 & 52.1 & 0.0281 & 24.7 & 33.3 & 168.5 & 33.4 & 2 & 0.80 & 24.8 & $\mathrm{n}=4$ & $5.7 \%$ \\
\hline & & & & & 0.0088 & 92.0 & $* 0.0003$ & 1.1 & 0.2 & 12.2 & 1.2 & 1 & 0.86 & 6.70 & $\mathrm{~N}=7$ & \\
\hline & & & & & 0.0062 & 55.2 & 0.0254 & 31.5 & 34.1 & 103.1 & 40.1 & 2 & 0.78 & 25.4 & & \\
\hline & & & & & 0.0045 & 53.2 & 0.0198 & 27.3 & 49.2 & 196.3 & 39.8 & 2 & 0.77 & 28.0 & & \\
\hline \multirow[t]{9}{*}{ 12KN10 } & 375 & 59.7330 & -150.7876 & graywacke & 0.0091 & 82.8 & 0.0059 & 1.6 & 6.0 & 191.1 & 4.0 & 1 & 0.87 & 43.1 & & \\
\hline & & & & & 0.0070 & 78.2 & 0.0236 & 11.5 & 25.9 & 183.4 & 18.5 & 1 & 0.85 & 42.0 & & \\
\hline & & & & & 0.0048 & 61.3 & 0.0090 & 5.2 & 16.8 & 175.5 & 10.0 & 2 & 0.80 & 46.8 & & \\
\hline & & & & & 0.0046 & 49.0 & 0.0069 & 5.1 & 12.3 & 150.4 & 8.7 & 2 & 0.75 & 46.1 & 47.0 & $3.1 \mathrm{Ma}$ \\
\hline & & & & & 0.0051 & 73.6 & 0.0153 & 8.9 & 20.8 & 191.7 & 14.7 & 1 & 0.83 & 48.4 & $\mathrm{n}=9$ & $6.6 \%$ \\
\hline & & & & & 0.0046 & 55.2 & 0.0097 & 6.2 & 18.1 & 220.3 & 11.6 & 2 & 0.79 & 47.1 & $\mathrm{~N}=9$ & \\
\hline & & & & & 0.0086 & 67.6 & 0.0172 & 6.0 & 15.3 & 182.4 & 10.5 & 2 & 0.83 & 46.6 & & \\
\hline & & & & & 0.0072 & 59.8 & 0.0127 & 4.2 & 16.3 & 131.3 & 8.7 & 2 & 0.80 & 50.9 & & \\
\hline & & & & & 0.0055 & 57.8 & 0.0109 & 5.0 & 16.7 & 161.5 & 9.7 & 2 & 0.79 & 51.5 & & \\
\hline \multirow[t]{2}{*}{$12 \mathrm{KN} 11$} & 820 & 59.6727 & -150.7210 & meta. sand & 0.0083 & 51.5 & 0.0271 & 11.6 & 35.4 & 280.1 & 21.3 & 5 & 0.76 & 40.4 & 41.6 & $1.6 \mathrm{Ma}$ \\
\hline & & & & & 0.0058 & 43.7 & 0.0101 & 5.2 & 24.9 & 151.4 & 11.8 & 5 & 0.69 & 42.7 & $\mathrm{n}=2 / \mathrm{N}=2$ & $4.0 \%$ \\
\hline \multirow[t]{13}{*}{$12 \mathrm{KN} 12$} & 602 & 59.5215 & -150.6630 & meta. sand & 0.0111 & 124.2 & 0.0353 & 12.6 & 51.2 & 296.3 & 26.1 & 1 & 0.88 & 27.0 & & \\
\hline & & & & & 0.0140 & 72.3 & 0.0185 & 10.0 & 14.6 & 201.8 & 14.5 & 4 & 0.83 & 21.9 & & \\
\hline & & & & & 0.0075 & 92.0 & 0.0155 & 53.8 & 1.5 & 242.8 & 55.4 & 1 & 0.86 & 8.41 & & \\
\hline & & & & & 0.0122 & 56.7 & 0.4918 & 29.4 & 31.7 & 298.0 & 38.4 & 4 & 0.77 & 262 & & \\
\hline & & & & & 0.0074 & 71.8 & 0.0209 & 18.4 & 28.1 & 242.0 & 26.2 & 3 & 0.83 & 25.7 & & \\
\hline & & & & & 0.0057 & 40.5 & 0.0027 & 4.2 & 17.3 & 209.0 & 9.3 & 4 & 0.68 & 15.6 & 22.0 & $5.8 \mathrm{Ma}$ \\
\hline & & & & & 0.0042 & 69.0 & 0.0031 & 4.4 & 11.1 & 257.1 & 8.3 & 1 & 0.82 & 23.0 & $\mathrm{n}=11$ & $26.4 \%$ \\
\hline & & & & & 0.0061 & 52.8 & 0.1312 & 5.0 & 13.4 & 234.4 & 9.3 & 4 & 0.77 & 611 & $\mathrm{~N}=13$ & \\
\hline & & & & & 0.0017 & 39.7 & 0.0050 & 24.6 & 31.1 & 248.2 & 33.2 & 3 & 0.68 & 25.2 & & \\
\hline & & & & & 0.0046 & 50.4 & 0.0046 & 4.9 & 17.1 & 238.2 & 10.1 & 3 & 0.75 & 27.1 & & \\
\hline & & & & & 0.0090 & 72.8 & 0.0162 & 12.0 & 22.5 & 214.0 & 18.3 & 3 & 0.82 & 23.6 & & \\
\hline & & & & & 0.0015 & 39.4 & 0.0283 & 288.1 & 63.8 & 309.8 & 304.7 & 4 & 0.67 & 18.4 & & \\
\hline & & & & & 0.0052 & 78.2 & 0.0185 & 23.4 & 27.6 & 266.4 & 31.2 & 1 & 0.84 & 26.4 & & \\
\hline \multirow[t]{4}{*}{$12 \mathrm{KN} 13$} & 657 & 59.5260 & -151.3715 & graywacke & 0.0093 & 82.8 & 0.0053 & 16.3 & 1.8 & 146.5 & 17.5 & 1 & 0.85 & 7.53 & & \\
\hline & & & & & 0.0084 & 78.2 & 0.0061 & 18.0 & 3.6 & 147.6 & 19.5 & 1 & 0.84 & 8.71 & 9.5 & $2.5 \mathrm{Ma}$ \\
\hline & & & & & 0.0069 & 73.6 & 0.0066 & 18.0 & 1.4 & 154.8 & 19.1 & 1 & 0.80 & 12.3 & $\mathrm{n}=3$ & $26.4 \%$ \\
\hline & & & & & 0.0117 & 39.9 & 0.0432 & 27.9 & 9.5 & 220.7 & 31.2 & 11 & 0.68 & 34.0 & $\mathrm{~N}=3$ & \\
\hline \multirow[t]{6}{*}{$12 \mathrm{KN} 15$} & 94 & 60.9093 & -149.6064 & meta. sand & 0.0057 & 64.4 & 0.0027 & 7.3 & 16.9 & 131.2 & 12.0 & 1 & 0.80 & 9.88 & & \\
\hline & & & & & 0.0068 & 69.0 & 0.0028 & 5.2 & 9.7 & 201.0 & 8.5 & 1 & 0.82 & 12.1 & & \\
\hline & & & & & 0.0067 & 78.2 & 0.0037 & 5.9 & 7.4 & 90.8 & 8.1 & 1 & 0.81 & 16.5 & 14.6 & 3.4 Ma \\
\hline & & & & & 0.0114 & 101.2 & 0.0202 & 15.4 & 25.7 & 239.9 & 22.6 & 1 & 0.87 & 17.7 & $\mathrm{n}=5$ & $23.3 \%$ \\
\hline & & & & & 0.0129 & 52.3 & 0.0243 & 15.4 & 21.2 & 104.0 & 20.9 & 5 & 0.75 & 23.2 & $\mathrm{~N}=6$ & \\
\hline & & & & & 0.0083 & 40.0 & 0.0206 & 30.8 & 45.2 & 154.4 & 42.2 & 6 & 0.68 & 16.6 & & \\
\hline \multirow[t]{2}{*}{$12 \mathrm{KN} 16$} & 1076 & 60.1800 & -149.7063 & meta.sand & 0.0137 & 45.9 & 0.0283 & 41.4 & 36.3 & 207.3 & 51.0 & 6 & 0.72 & 10.8 & & \\
\hline & & & & & 0.0057 & 92.0 & 0.0117 & 21.2 & 55.2 & 245.7 & 35.4 & 1 & 0.86 & 13.2 & & \\
\hline
\end{tabular}




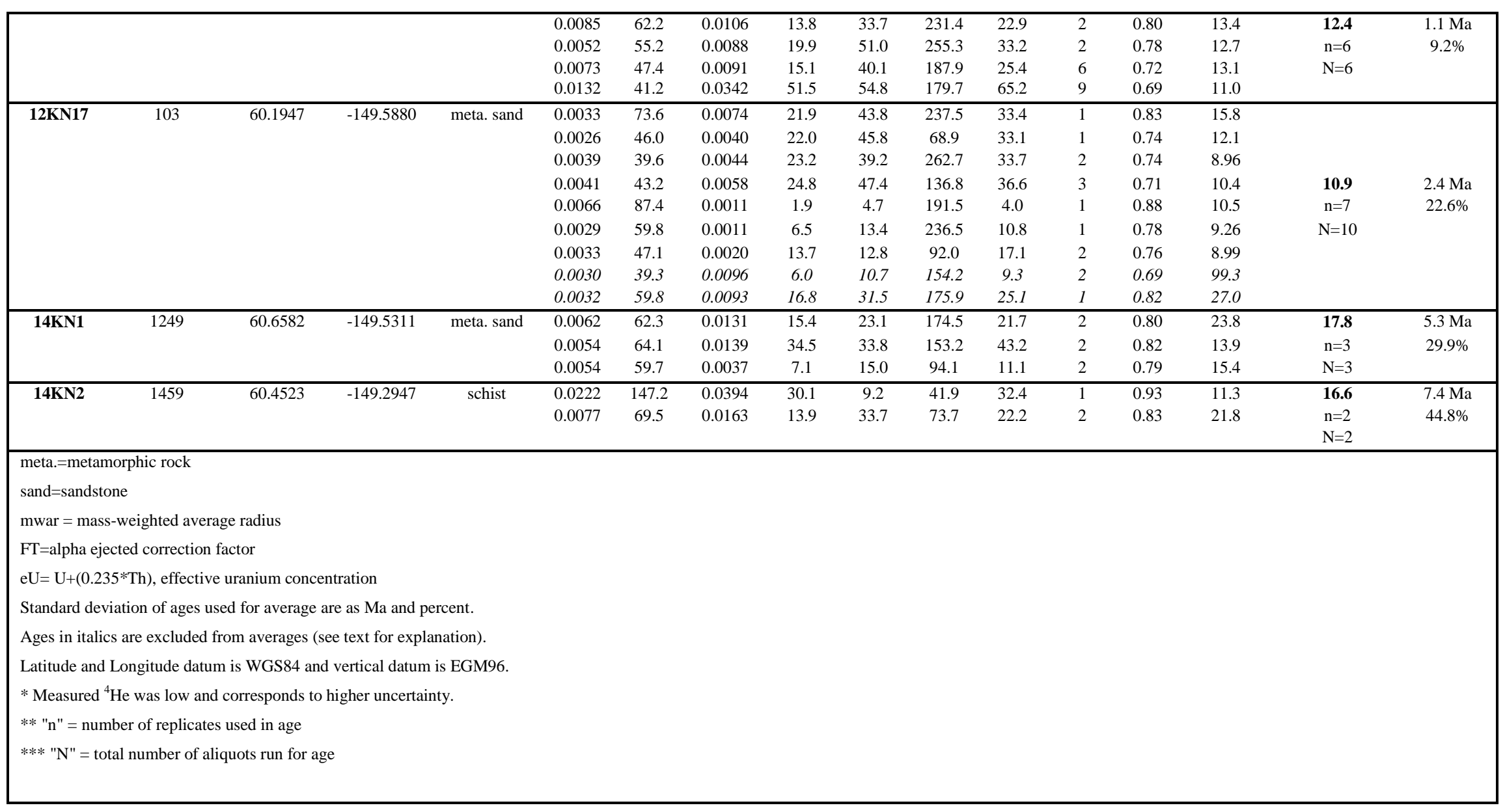

